\title{
Potential Applications of Moringa oleifera in Poultry Health and Production as Alternative to Antibiotics: A Review
}

\author{
Rifat Ullah Khan ${ }^{1}$ (D), Aamir Khan ${ }^{2}$, Shabana Naz ${ }^{3}$, Qudrat Ullah ${ }^{1}$, Vito Laudadio ${ }^{4}$, Vincenzo Tufarelli ${ }^{4, *}$ (D) \\ and Marco Ragni ${ }^{5}$ (D)
}

1 Faculty of Animal Husbandry and Veterinary Sciences, College of Veterinary Sciences, The University of Agriculture, Peshawar 25130, Pakistan; rukhan@aup.edu.pk (R.U.K.); qudrat@gmail.com (Q.U.)

2 Directorate General (Research), Livestock and Dairy Development Department, Peshawar 10320, Pakistan; aamirkhanbannuzai@gmail.com

3 Department of Zoology, Government College University, Faisalabad 38000, Pakistan; drahabananaz@gxfu.edu.pk

4 Department of DETO, Section of Veterinary Science and Animal Production, University of Bari 'Aldo Moro', Valenzano, 70010 Bari, Italy; vito.laudadio@uniba.it

5 Department of Agro-Environmental and Territorial Science, University of Bari 'Aldo Moro', 70125 Bari, Italy; marco.ragni@uniba.it

* Correspondence: vincenzo.tufarelli@uniba.it

Citation: Khan, R.U.; Khan, A.; Naz, S.; Ullah, Q.; Laudadio, V.; Tufarelli, V.; Ragni, M. Potential Applications of Moringa oleifera in Poultry Health and Production as Alternative to Antibiotics: A Review. Antibiotics 2021, 10, 1540. https://doi.org/ 10.3390/antibiotics 10121540

Academic Editor: William N. Setzer

Received: 24 November 2021

Accepted: 12 December 2021

Published: 16 December 2021

Publisher's Note: MDPI stays neutral with regard to jurisdictional claims in published maps and institutional affiliations.

Copyright: (c) 2021 by the authors. Licensee MDPI, Basel, Switzerland. This article is an open access article distributed under the terms and conditions of the Creative Commons Attribution (CC BY) license (https:/ / creativecommons.org/licenses/by/ $4.0 /)$.

\begin{abstract}
Because of developing bacterial resistance and increased public awareness of health and food safety problems, the use of antibiotics as growth promoters in the chicken industry has been outlawed. This problem has spurred the poultry industry and sector to explore for safe antibiotic alternatives and to focus on developing better long-term feed management solutions in order to improve chicken health and growth. As a result, phytogenics have developed as natural antibiotic alternatives, with a lot of potential in the poultry industry. Moringa oleifera has gotten a lot of attention from researchers in the recent past as a natural product with a lot of health advantages for poultry. Moringa is known for its antimicrobial, antioxidant, anti-inflammatory, and hypocholesterolemic properties, as well as its capacity to activate digestive enzymes in the stomach, owing to the presence of hundreds of essential ingredients. The potential influence of $M$. oleifera as a natural feed supplement on overall gut health, nutritional digestibility, blood biochemical profile, antioxidant benefits, antibacterial potential, and immunological response is emphasized in this review.
\end{abstract}

Keywords: alternative to antibiotics; Moringa oleifera; poultry; nutrition; health

\section{Introduction}

Antibiotics are commonly administered in chicken feed and water for a variety of reasons. These drugs may be used to treat a variety of infectious disorders, mostly microbial infections. Antibiotics could also be used sub-therapeutically or prophylactically in order to avoid infections and also as a growth stimulant to improve performance and feed efficiency, however, their extensive use has resulted in antimicrobial resistance. Antibiotic resistance develops as a result of humans eating meat and eggs carrying antibiotic residues [1]. The European Union has outlawed the use of antibiotics in order to reduce their toxicity [2]. Therefore, to replace antibiotics as a growth stimulant, alternate sources are now required.

The banning of antibiotics as growth promoters, which has triggered research into alternative to antibiotics, such as probiotics [3-10], prebiotics [11-14], enzymes [15-18], organic acids [19,20], herbs [21-36] and other compounds [37,38], has been reported in poultry production (Figure 1). Researchers are developing phytogenics for usage in chickens with many advantages, such as increased feed efficiency, improved immunological status, and improved gastrointestinal health, in addition to others [39-48]. To the best of our knowledge, no review is currently available on the research outcome of Moringa oleifera 
on the growth and health aspects of poultry. Therefore, the purpose of this review was to outline the updated knowledge on M. oleifera on the production and health of poultry.

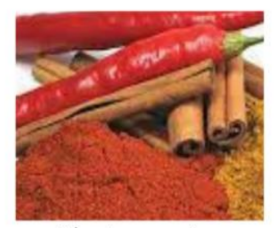

Phytogenics

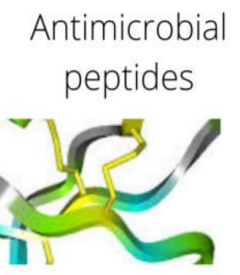

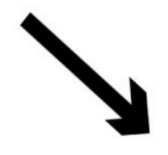

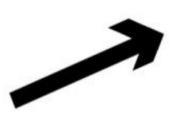

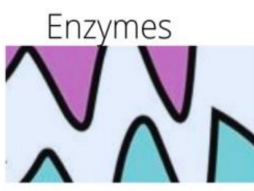
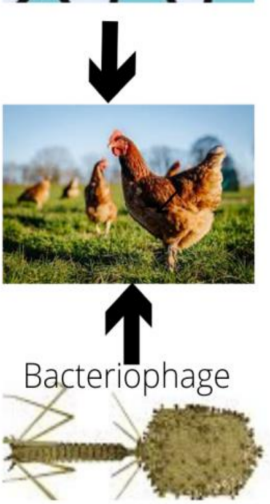
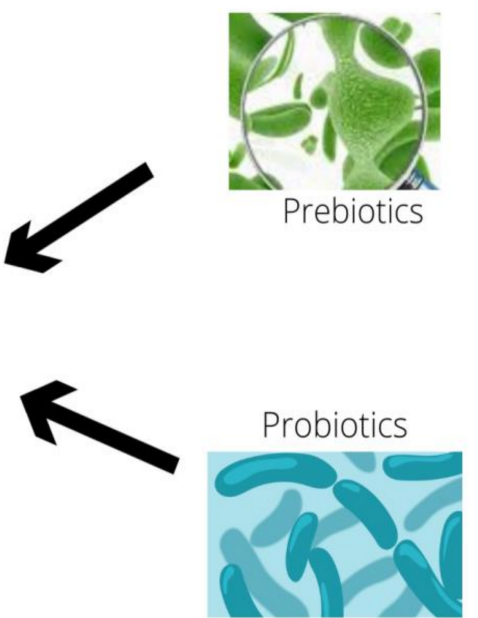

Figure 1. Example of some alternatives to antibiotics in poultry.

M. oleifera is a tiny, drought-resistant deciduous tree with a height of 5 to $12 \mathrm{~cm}$ [49]. It has an outstanding capacity to provide nutritional, medicinal, and industrial uses to humans, as well as for animal fodder [50]. It is high in amino acids, beta-carotene, ascorbic acid, and vitamins. Because of its exceptional therapeutic and medicinal properties, it may be used as a medication to treat a variety of ailments [51]. It can also be utilized as a growth stimulant, antioxidant and antimicrobial agent [52]. The presence of caffeic acid and cinnamic acid gives it antioxidant benefits [53]. It was reported that this plant has over 92 useful components, including 36 anti-inflammatory agents, 46 antioxidants, and 18 amino acids [54]. The chemical composition of M. oleifera is given in Table 1.

Table 1. Chemical composition of M. oleifera (adapted from Moyo et al. [55]; Aja et al. [56]; Sobhy et al. [57].

\begin{tabular}{|c|c|c|c|c|c|c|c|}
\hline $\begin{array}{c}\text { Proximate } \\
\text { Analysis }\end{array}$ & $\%$ & $\begin{array}{c}\text { Essential } \\
\text { Amino Acids }\end{array}$ & $\mathrm{mg} / 100 \mathrm{~g}$ & $\begin{array}{l}\text { Non-Essential } \\
\text { Amino Acids }\end{array}$ & $\mathrm{mg} / 100 \mathrm{~g}$ & Vitamins & $\mathrm{mg} / 100 \mathrm{~g}$ \\
\hline Carbohydrates & 23.6 & Leucine & 94.36 & Glutamic Acid & 18.03 & Vitamin A ( $\beta$-Carotene) & 16.3 \\
\hline Crude fiber & 35.0 & Lysine & 69.13 & Aspartic Acid & 13.76 & Vitamin B1 (Thiamine) & 2.64 \\
\hline Moisture & 10.0 & Valine & 62.34 & Arginine & 7.65 & Vitamin B2 (Riboflavin) & 20.5 \\
\hline Ash & 10.0 & Threonine & 48.35 & Alanine & 4.93 & $\begin{array}{l}\text { Vitamin B3 (Nicotinic } \\
\text { acid) }\end{array}$ & 8.2 \\
\hline Crude protein & 30.29 & Isoleucine & 46.98 & Serine & 3.13 & Vitamin C (Ascorbic acid) & 17.3 \\
\hline Crude fat & 6.50 & Histidine & 29.56 & Glycine & 2.31 & $\begin{array}{l}\text { Vitamin } \mathrm{E} \text { (Tocopherol } \\
\text { acetate) }\end{array}$ & 113 \\
\hline \multicolumn{2}{|c|}{ Macrominerals } & \multicolumn{2}{|c|}{ Composition (\%) } & \multicolumn{2}{|c|}{ Fatty Acids } & \multicolumn{2}{|l|}{ Composition (\%) } \\
\hline \multicolumn{2}{|c|}{ Calcium } & \multicolumn{2}{|c|}{3.65} & \multicolumn{2}{|c|}{ Capric (C10) } & \multicolumn{2}{|l|}{0.07} \\
\hline \multicolumn{2}{|c|}{ Potassium } & \multicolumn{2}{|c|}{1.50} & \multicolumn{2}{|c|}{ Lauric (C12) } & \multicolumn{2}{|l|}{0.58} \\
\hline \multicolumn{2}{|c|}{ Sulphur } & \multicolumn{2}{|c|}{0.63} & \multicolumn{2}{|c|}{ Myristic (C14) } & \multicolumn{2}{|l|}{3.66} \\
\hline \multicolumn{2}{|c|}{ Magnesium } & \multicolumn{2}{|c|}{0.50} & \multicolumn{2}{|c|}{ Palmitic (C16) } & \multicolumn{2}{|l|}{11.76} \\
\hline \multicolumn{2}{|c|}{ Phosphorus } & \multicolumn{2}{|c|}{0.30} & \multicolumn{2}{|c|}{ Margaric (C17) } & \multicolumn{2}{|l|}{3.19} \\
\hline \multicolumn{2}{|c|}{ Sodium } & \multicolumn{2}{|c|}{0.164} & \multicolumn{2}{|c|}{ Stearic (C18) } & \multicolumn{2}{|l|}{2.13} \\
\hline & & & & \multicolumn{2}{|c|}{ Arachidic (C20) } & \multicolumn{2}{|l|}{1.61} \\
\hline
\end{tabular}


Table 1. Cont.

\begin{tabular}{cccc}
\hline Microminerals $\mathbf{( m g / k g )}$ & Heneicosylic (C21) & 14.41 & 1.24 \\
\hline Zinc & 31.03 & Behenic (C22) & 0.66 \\
\hline Copper & 8.25 & Tricossylic (C23) & 2.91 \\
\hline Manganese & 86.8 & Lignoceric (C24) & \\
\hline Iron & 490 & & \\
\hline Selenium & 363 & & \\
\hline Boron & 49.93 & & \\
\hline
\end{tabular}

The leaves have a protein content of $25-27 \%$, which is exceptional for animals. It has been estimated that the amino acid profiles of the M. oleifera leaves and soya-bean meal are identical [58]. The M. oleifera leaves contain a high protein content of $20-33 \%$ on a dry matter basis, with all of the necessary amino acids [59]. A study reported that M. oleifera has three times the iron content of spinach and four glasses of milk, four times the vitamin A content of carrots, and two times the protein content of milk [60]. Moringa is used fresh, and as powder, as well as commercial preparations (Figure 2 and Table 2).

Table 2. Effects of M. oleifera on different parameters of poultry.

\begin{tabular}{|c|c|c|c|c|}
\hline Parameter & Dose & Source & Effect & Reference \\
\hline \multirow{24}{*}{ Feed intake } & $5 \%$ & MOLM & Increased & El-Tazi et al. [61] \\
\hline & $10 \%$ & MOLM & Increased & Ebenebe et al. [62] \\
\hline & 0.25 and $0.40 \%$ & MOL & Increased & $\begin{array}{c}\text { Avijit Dey and Partha Sarathi } \\
\text { De [63] }\end{array}$ \\
\hline & 3,5 and $7 \mathrm{~g} / \mathrm{kg}$ diet & MOLM & Increased & Ahmed and El-Rayes [64] \\
\hline & 2.5 and $5 \%$ & MOLM & Increased & Mikhail et al. [65] \\
\hline & 200 and $400 \mathrm{ppm}$ & MOEO & Increased & Tekce et al. [66] \\
\hline & $0.3 \%$ & MOLP & Increased & Abou-Elkhair et al. [67] \\
\hline & $8.0 \%$ & MOLM & Improved & Egu [68] \\
\hline & $60-120 \mathrm{~mL} / \mathrm{L}$ & MOLE & No effect & Khan et al. [35] \\
\hline & 5,10 or $15 \%$ & MOL & No effect & Lu et al. [69] \\
\hline & $1.2 \%$ & MOLP & No effect & Khan et al. [70] \\
\hline & $1 \mathrm{~g} / \mathrm{kg}$ & MOL and MOS and their combination & No effect & Ashour et al. [71] \\
\hline & 7,14 and $21 \%$ & M. oleifera leaf flour & No effect & Castillo et al. [72] \\
\hline & $2.5,5$ and $7.5 \%$ & MOLM & No effect & Atuahene et al. [73] \\
\hline & $5-10 \%$ & MOLM & Decreased & Ash et al. [74] \\
\hline & $1 \%$ & MOLE & Decreased & Paul et al. [75] \\
\hline & $90 \mathrm{~mL}$ & MOLE & Decreased & Alabi et al. [76] \\
\hline & $5 \%$ & MOS & Decreased & Riry et al. [77] \\
\hline & $0.2 \%$ & MOLM & Decreased & Elkloub et al. [78] \\
\hline & $15 \%$ & MOLM & Decreased & Hassan et al. [79] \\
\hline & $0.75 \%$ & MOSP & Decreased & Wahab et al. [80] \\
\hline & 0.4 to $0.6 \%$ & $\begin{array}{l}\text { Phytogenic feed mixture contained } \\
\text { equal ratios of black cumin, } M \text {. oleifera } \\
\text { and chicory seeds }\end{array}$ & Decreased & Arif et al. [81] \\
\hline & $90 \mathrm{~mL} / \mathrm{L}$ & MOLE & Decreased & Kumar et al. [82] \\
\hline & $5 \%$ & MOL & Improved & Hafsa et al. [83] \\
\hline
\end{tabular}


Table 2. Cont.

\begin{tabular}{|c|c|c|c|c|}
\hline Parameter & Dose & Source & Effect & Reference \\
\hline \multirow{24}{*}{ Feed efficiency } & $750 \mathrm{~g} / 100 \mathrm{~kg}$ & MOLM & Improved & Atuahene et al. [73] \\
\hline & $90 \mathrm{~mL}$ & MOLE & Improved & Alabi et al. [76] \\
\hline & $1 \%$ & MOLE & Improved & Paul et al. [75] \\
\hline & $5 \%$ & MOLM & Improved & El-Tazi et al. [61] \\
\hline & 5,10 or $15 \%$ & MOL & Improved & Lu et al. [69] \\
\hline & $0.2 \%$ & MOLM & Improved & Elkloub et al. [78] \\
\hline & 0.25 to $0.50 \%$ & MOLM & Improved & Talukdar et al. [84] \\
\hline & $0.1 \%$ & MOLM & Improved & Kulkarni et al. [85] \\
\hline & 3,5 and $7 \mathrm{~g} / \mathrm{kg}$ diet & MOL & Improved & Ahmed and El-Rayes [64] \\
\hline & 7,14 and $21 \%$ & M. oleifera leaf flour & Improved & Castillo et al. [72] \\
\hline & 2.5 and $5 \%$ & MOLM & Improved & Mikhail et al. [65] \\
\hline & 200 and $400 \mathrm{ppm}$ & dietary MOEO & Improved & Tekce et al. [66] \\
\hline & $0.3 \%$ & M. oleifera seed powder & Improved & Abou-Elkhair et al. [67] \\
\hline & $8.00 \%$ & MOLM & Improved & Egu [68] \\
\hline & $0.75 \%$ & MOSP & Improved & Wahab et al. [80] \\
\hline & 0.4 to $0.6 \%$ & $\begin{array}{l}\text { Phytogenic feed mixture contained } \\
\text { equal ratios of black cumin, Moringa } \\
\text { oleifera and chicory seeds }\end{array}$ & Improved & Arif et al. [81] \\
\hline & $90 \mathrm{~mL} / \mathrm{L}$ & MOLE & Improved & Kumar et al. [82] \\
\hline & $5 \%$ & MOL & Improved & Hafsa et al. [83] \\
\hline & $60-120 \mathrm{~mL} / \mathrm{L}$ & MOLE & No effect & Khan et al. [35] \\
\hline & $1 \mathrm{~g} / \mathrm{kg}$ & MOL and MOS and their combination & No effect & Ashour et al. [71] \\
\hline & $1.2 \%$ & MOLP & No effect & Khan et al. [70] \\
\hline & $1-2 \%$ & MOLM & No effect & Kwariet et al. [86] \\
\hline & $15 \%$ & MOL & No effect & Kakengi et al. [87] \\
\hline & 5,10 and $15 \%$ & MOLM & Decreased & Zanu et al. [88] \\
\hline \multirow{24}{*}{ Body weight } & $5 \%$ & MOLM & Increased & El-Tazi et al. [61] \\
\hline & $1 \%$ & MOLM & Increased & Kakengi et al. [89] \\
\hline & $1 \%$ & MOLM & Increased & Olugbemi et al. [90] \\
\hline & $1 \%$ & MOLM & Increased & Banjo [91] \\
\hline & $10 \%$ & MOLM & Increased & Ebenebe et al. [62] \\
\hline & $1.2 \%$ & MOLP & Increased & Khan et al. [70] \\
\hline & 0.25 and $0.40 \%$ & MOL & Increased & $\begin{array}{c}\text { Avijit Dey and Partha Sarathi } \\
\text { De [63] }\end{array}$ \\
\hline & $0.2 \%$ & MOLM & Increased & Elkloub et al. [78] \\
\hline & 0.25 to $0.50 \%$ & MOLM & Increased & Talukdar et al. [84] \\
\hline & $0.1 \%$ & MOLM & Increased & Kulkarni et al. [85] \\
\hline & 3,5 and $7 \mathrm{~g} / \mathrm{kg}$ diet & MOLM & Increased & Ahmed and El- Rayes [64] \\
\hline & 2.5 and $5 \%$ & MOLM & Improved & Mikhail et al. [65] \\
\hline & $8.00 \%$ & MOLM & Improved & Egu [68] \\
\hline & $0.75 \%$ & MOSP & Improved & Wahab et al. [80] \\
\hline & 0.4 to $0.6 \%$ & $\begin{array}{l}\text { Phytogenic feed mixture contained } \\
\text { equal ratios of black cumin, } M \text {. oleifera } \\
\text { and chicory seeds }\end{array}$ & Improved & Arif et al. [81] \\
\hline & $90 \mathrm{~mL} / \mathrm{L}$ & MOLE & Improved & Kumar et al. [82] \\
\hline & $5 \%$ & MOL & Improved & Hafsa et al. [83] \\
\hline & $60-120 \mathrm{~mL} / \mathrm{L}$ & MOLE & No effect & Khan et al. [35] \\
\hline & 5,10 or $15 \%$ & MOL & No effect & Lu et al. [69] \\
\hline & $5 \%$ & MOL & No effect & Kilany et al. [92] \\
\hline & 5,10 and $15 \%$ & MOLM & Decreased & Zanu et al. [88] \\
\hline & 5 and $10 \%$ & MOLM & Decreased & Olugbemi et al. [90] \\
\hline & $90 \mathrm{~mL}$ & MOLE & Decreased & Alabi et al. [76] \\
\hline & 7,14, and $21 \%$ & M. oleifera (MOR) leaf flour & Decreased & Castillo et al. [72] \\
\hline
\end{tabular}


Table 2. Cont.

\begin{tabular}{|c|c|c|c|c|}
\hline Parameter & Dose & Source & Effect & Reference \\
\hline \multirow{12}{*}{$\begin{array}{l}\text { Overall growth } \\
\text { performance }\end{array}$} & 200 and 400 ppm & dietary MOEO & Improved & Tekce et al. [66] \\
\hline & $15 \%$ & MOLM & Improved & Hassan et al. [79] \\
\hline & 2.5 and $5 \%$ & MOLM & Improved & Mikhail et al. [65] \\
\hline & $8.00 \%$ & MOLM & Improved & Egu [68] \\
\hline & $0.75 \%$ & MOSP (Moringa oleifera seed powder) & Improved & Wahab et al. [80] \\
\hline & 0.4 to $0.6 \%$ & $\begin{array}{l}\text { Phytogenic feed mixture (BMC) } \\
\text { contained equal ratios of black cumin, } \\
\text { Moringa oleifera and chicory seeds }\end{array}$ & Improved & Arif et al. [81] \\
\hline & $90 \mathrm{~mL} / \mathrm{L}$ & MOLE & Improved & Kumar et al. [82] \\
\hline & $5 \%$ & MOL & Improved & Hafsa et al. [83] \\
\hline & $0.5,1.0,2.0$ and $3.0 \%$ & MOLM & No effect & Du et al. [93] \\
\hline & 5,10 or $15 \%$ & MOL & No effect & Lu et al. [69] \\
\hline & $5-10 \%$ & MOLM & Decreased & Ash et al. [71] \\
\hline & $10,15,20$ and $25 \%$ & MOSM & Decreased & Hassan et al. [79] \\
\hline \multirow{11}{*}{$\begin{array}{l}\text { Carcass traits: dressing } \\
\text { pertentage }\end{array}$} & $60-120 \mathrm{~mL} / \mathrm{L}$ & MOLE & Improved & Khan et al. [35] \\
\hline & $1.5 \%$ & M. oleifera dietary supplementation & Improved & Mousa et al. [94] \\
\hline & $5 \%$ & MOLM & Improved & El-Tazi et al. [61] \\
\hline & 2,4 and $6 \%$ & Moringa & Improved & Melesse et al. [95] \\
\hline & 3,5 and $7 \mathrm{~g} / \mathrm{kg}$ & MOLM & Improved & Ahmed and El-Rayes [64] \\
\hline & $5 \%$ & MOLM & Improved & Mikhail et al. [65] \\
\hline & $1 \%$ & MOL & Improved & Hafsa et al. [83] \\
\hline & $5,10,15 \%$ & MOLM & No effect & Zanu et al. [88] \\
\hline & 7,14, and $21 \%$ & MOLP & No effect & Castillo et al. [72] \\
\hline & $5-20 \%$ & MOL & Decreased & Tesfaye et al. [96] \\
\hline & $5,7.5$ and $10 \%$ & MOLM & Decreased & Onunkwo and George [97] \\
\hline \multirow{13}{*}{$\begin{array}{c}\text { Egg production and } \\
\text { quality }\end{array}$} & $1 \mathrm{~g} / \mathrm{kg}$ & MOL and MOS and their combination & Improved & Ashour et al. [71] \\
\hline & $300 \mathrm{~g}$ & MOL & Improved & Mohammed et al. [98] \\
\hline & $15 \%$ & MOL & Improved & Ebenebe et al. [62] \\
\hline & $5 \%$ & MOL & Improved & Donsbough et al. [99] \\
\hline & $1 \%$ & MOLM & improved & Yadav et al. [100] \\
\hline & $4-6 \%$ & MOP & improved & Siti et al. [101] \\
\hline & $0.3 \%$ & MOP & improved & Abou-Elkhair et al. [67] \\
\hline & $1-2 \%$ & MOLM & No effect & Kwariet et al. [86] \\
\hline & $20 \%$ & MOLM & No effect & Abdelnour et al. [102] \\
\hline & $1 \%$ & MOLM & $\begin{array}{l}\text { No effect except yolk color } \\
\text { improved }\end{array}$ & Talukdar et al. [84] \\
\hline & $15 \%$ & MOL & Decreased & Lu et al. [69] \\
\hline & $20 \%$ & MOLM & Decreased & Olugbemi et al. [90] \\
\hline & $15 \%$ & MOL & Decreased & Abou-Elezz et al. [103] \\
\hline \multirow{11}{*}{$\begin{array}{l}\text { Antioxidant effects } \\
\text { (MDA concentration) }\end{array}$} & $5 \%$ & MOL & Decreased MDA level & Balami et al. [104] \\
\hline & 500 and $1000 \mathrm{mg} / \mathrm{kg}$ & MOL & Decreased MDA level & Rao et al. [105] \\
\hline & $0.5 \%, 1.0 \%$, and $1.5 \%$ & MOLM & Decreased MDA level & Karthivashan et al. [106] \\
\hline & $1,2,5,10$, and $15 \%$ & MOL & Decreased MDA level & Cui et al. [107] \\
\hline & $(1 \mathrm{~g})$ & MOLP & Decreased MDA level & Ratshilivha et al. [108] \\
\hline & $60-120 \mathrm{~mL} / \mathrm{L}$ & MOLE & Decreased MDA level & Khan et al. [35] \\
\hline & $0.4 \& 0.6 \%$ & MOLM & Decreased MDA level & Elkloub et al. [78] \\
\hline & $90 \mathrm{~mL} / \mathrm{L}$ & MOLE & Decreased MDA level & Kumar et al. [82] \\
\hline & $5 \%$ & MOL & $\begin{array}{l}\text { Lowest TBARS level in the } \\
\text { blood serum of broilers }\end{array}$ & Hafsa et al. [83] \\
\hline & $5 \%$ & MOL & No effect & Kilany et al. [92] \\
\hline & $15 \%$ & MOL & Increased MDA level & Lu et al. [69] \\
\hline
\end{tabular}


Table 2. Cont.

\begin{tabular}{|c|c|c|c|c|}
\hline Parameter & Dose & Source & Effect & Reference \\
\hline \multirow{6}{*}{ Antibacterial activity } & $\begin{array}{l}10 \mathrm{gm} \text { of collected } \\
\text { powdered form of leaves, } \\
\text { flower, seed and pulp }\end{array}$ & Extracts of MOLE & $\begin{array}{l}\text { Active against } E \text {. coli and } S . \\
\text { aureus }\end{array}$ & Bijal and Bhumika [109] \\
\hline & $\begin{array}{l}\text { Powder }(200 \mathrm{~g}) \text { was } \\
\text { extracted with methanol }\end{array}$ & MOLE methanolic extracts & $\begin{array}{c}\text { Effective against } \\
\text { Gram-negative bacterial } \\
\text { strains }\end{array}$ & Dzotam et al. [110] \\
\hline & Powder (200 g) & Extracts of MOLE & $\begin{array}{c}\text { Effective against different } \\
\text { bacterial strains }\end{array}$ & Patel and Mohan [111] \\
\hline & Powder (200 g) & M. oleifera seeds oil & Effective against $E$. coli & Bichi and Shehu [112] \\
\hline & $14 \%$ & MOLP & $\begin{array}{l}\text { Effective against both } \\
\text { Gram-positive and } \\
\text { Gram-negative bacteria }\end{array}$ & Castillo et al. [72] \\
\hline & $0.5,1$ and $5 \%$ & MOL & $\begin{array}{l}\text { Decreased ileal counts of } E . \\
\text { coli, Salmonella and } \\
\text { Staphylococcus. spp. while } \\
\text { total ileal Lactobacillus spp. } \\
\text { count increased }\end{array}$ & Hafsa et al. [83] \\
\hline \multirow[b]{2}{*}{ Antiviral activity } & 10 and $20 \%$ & M. oleifera supplementation & Improved & Mariana et al. [113] \\
\hline & $200 \mu \mathrm{g} / \mathrm{mL}$ & MOLE & $\begin{array}{l}\text { Effective against herpes } \\
\text { simplex virus type } 1 \text { and } 2\end{array}$ & Mohamed et al. [114] \\
\hline \multirow{8}{*}{$\begin{array}{l}\text { Antibody response } \\
\text { against NDV }\end{array}$} & $60-120 \mathrm{~mL} / \mathrm{L}$ & MOLE & Improved & Khan et al. [35] \\
\hline & 500 and $1000 \mathrm{mg} / \mathrm{kg}$ & MOL & Improved & Rao et al. [105] \\
\hline & $1.5 \%$ & M. oleifera supplementation & Improved & Mousa et al. [94] \\
\hline & $15 \%$ & MOLM & Improved & Hassan et al. [79] \\
\hline & $0.75 \%$ & MOLP & Improved & Wahab et al. [80] \\
\hline & $90 \mathrm{~mL} / \mathrm{L}$ & MOLE & Improved & Kumar et al. [82] \\
\hline & $5 \%$ & MOL & No effect & Kilany et al. [92] \\
\hline & $10,15,20$ and $25 \%$ & MOSM & Decreased & Hassan et al. [79] \\
\hline $\begin{array}{l}\text { Antibody response } \\
\text { against IBV }\end{array}$ & $60-120 \mathrm{~mL} / \mathrm{L}$ & MOLE & Improved & Khan et al. [35] \\
\hline $\begin{array}{l}\text { Antibody response } \\
\text { against IB }\end{array}$ & $200 \mu \mathrm{g} / \mathrm{mL}$ & MOLE & $\begin{array}{l}\text { Effective against herpes } \\
\text { simplex virus type } 1 \text { and } 2\end{array}$ & Mohamed et al. [114] \\
\hline \multirow[b]{2}{*}{ Antifungal activity } & $\begin{array}{l}100 \mathrm{~g} / \mathrm{L} \text { ethanolic } \\
\text { solvents }\end{array}$ & $\begin{array}{c}\text { Extract of } M \text {. oleifera (Bark seed and } \\
\text { Leaf) Crude extracts }\end{array}$ & $\begin{array}{l}\text { Effective against mycelia } \\
\text { growth of Aspergillus flavus }\end{array}$ & Aondo et al. [115] \\
\hline & & $\begin{array}{l}\text { n- Hexane, ethyl acetate, methanol and } \\
\text { distilled water Leaf, stem, flower and } \\
\text { fruit extracts of } M \text {. oleifera }\end{array}$ & $\begin{array}{c}\text { Effective against } \text { Aspergillus } \\
\text { niger, Aspergillus paracitic, } \\
\text { Candida Albicans, Aspergillus } \\
\text { flavus, Trichoderma harzanium, } \\
\text { Alternata burnsi, Fusarium } \\
\text { oxysporum }\end{array}$ & Patel and Mohan [111] \\
\hline \multirow{3}{*}{ Anticoccidial activity } & $\begin{array}{c}1.0,2.0,3.0,4.0 \text { and } \\
5.0 \mathrm{~g} / \mathrm{kg} \text { body weigh }\end{array}$ & Acetone extract MOLE & $\begin{array}{c}\text { Inhibitory effect on oocyst } \\
\text { shed in the faeces }\end{array}$ & Fadunsin and Ademola [116] \\
\hline & 0.5 and $1 \%$ & Moringa olifera powder & $\begin{array}{l}\text { Effective against coccidial } \\
\text { activity }\end{array}$ & Banna et al. [117] \\
\hline & $10 \%$ ethanolic extract & MOLP & $\begin{array}{l}\text { Not Effective to inhibit or } \\
\text { disrupt sporulation of Eimeria } \\
\text { species oocysts of the } \\
\text { chickens }\end{array}$ & Gadelhaq et al. [118] \\
\hline \multirow{6}{*}{ Blood biochemistry } & \multirow[t]{2}{*}{5,10 and $15 \%$} & \multirow[t]{2}{*}{ MOLM } & $\begin{array}{l}\text { Significant effect on } \\
\text { Triglycerides, LDL, VLDL } \\
\text { and plasma glucose } \\
\text { concentration }\end{array}$ & \multirow[t]{2}{*}{ Zanu et al. [88] } \\
\hline & & & $\begin{array}{l}\text { Non-significant on blood } \\
\text { parameter and Mean } \\
\text { Corpuscular Hemoglobin } \\
\text { (MCH) \& plasma protein }\end{array}$ & \\
\hline & $10,15,20$ and $25 \%$ & MOSM & Increased plasma protein & Hassan et al. [79] \\
\hline & $5-20 \%$ & MOLE & Increased plasma protein & Tesfaye et al. [96] \\
\hline & \multirow{2}{*}{$60-120 \mathrm{~mL} / \mathrm{L}$} & \multirow{2}{*}{ MOLE } & $\begin{array}{l}\text { Increased serum protein } \\
\text { concentration }\end{array}$ & \multirow{2}{*}{ Khan et al. [35] } \\
\hline & & & $\begin{array}{l}\text { Decreased serum glucose } \\
\text { concentration }\end{array}$ & \\
\hline
\end{tabular}


Table 2. Cont.

\begin{tabular}{|c|c|c|c|c|}
\hline Parameter & Dose & Source & Effect & Reference \\
\hline & 10,30 and $50 \mathrm{~mL} / \mathrm{L}$ & MOL & $\begin{array}{l}\text { Decreased plasma glucose } \\
\text { concentration }\end{array}$ & Mahmood et al. [119] \\
\hline & $0.5,1.0,2.0$ and $3.0 \%$ & MOLM & $\begin{array}{l}\text { Significant effect on Mean } \\
\text { Corpuscular Hemoglobin } \\
\text { (MCH) }\end{array}$ & Du et al. [93] \\
\hline & \multirow[t]{2}{*}{$0.25 \%$ and $0.40 \%$} & \multirow[t]{2}{*}{ MOL } & $\begin{array}{c}\text { Decreased triglyceride, } \\
\text { LDL-cholesterol, plasma total } \\
\text { cholesterol }\end{array}$ & \multirow[t]{2}{*}{$\begin{array}{c}\text { Avijit Dey and Partha Sarathi } \\
\text { De [63] }\end{array}$} \\
\hline & & & Increased HDL-cholesterol & \\
\hline & \multirow{2}{*}{$15 \%$} & \multirow{2}{*}{ MOL } & Higher AST activities & \multirow{2}{*}{ Donsbough et al. [99] } \\
\hline & & & Wer ALB and UA levels & \\
\hline & 5,10 or $15 \%$ & MOL & $\begin{array}{l}\text { Decreased albumen (ALB) } \\
\text { and urea (UA) }\end{array}$ & Lu et al. [69] \\
\hline & \multirow{2}{*}{$1 \mathrm{~g} / \mathrm{kg}$} & \multirow[t]{2}{*}{ MOLE and MOLP } & $\begin{array}{c}\text { Decreased blood aspartate } \\
\text { transaminase (AST) and urea, } \\
\text { triglycerides and total } \\
\text { cholesterol }\end{array}$ & \multirow[t]{2}{*}{ Ashour et al. [71] } \\
\hline & & & $\begin{array}{l}\text { No significant effect on } \\
\text { alanine aminotransferase } \\
\text { (ALT), albumin, total protein, } \\
\text { globulin }\end{array}$ & \\
\hline & \multirow[b]{2}{*}{$0.2,0.4$ and $0.6 \%$} & \multirow[b]{2}{*}{ MOLM } & $\begin{array}{l}\text { Increased HDL, total protein } \\
\text { and globulin }\end{array}$ & \multirow[b]{2}{*}{ Elkloub et al. [78] } \\
\hline & & & $\begin{array}{c}\text { Decreased plasma ALT \& } \\
\text { AST, plasma cholesterol \& } \\
\text { LDL. }\end{array}$ & \\
\hline & $8 \%$ & MOLM & $\begin{array}{l}\text { Decreased glucose and } \\
\text { cholesterol levels }\end{array}$ & Egu [68] \\
\hline & $0.75 \%$ & MOSP & $\begin{array}{l}\text { Decreased total cholesterol } \\
\text { and LDL }\end{array}$ & Wahab et al. [80] \\
\hline & 0.4 to $0.6 \%$ & $\begin{array}{l}\text { Phytogenic feed mixture contained } \\
\text { equal ratios of black cumin, } M \text {. oleifera } \\
\text { and chicory seeds }\end{array}$ & $\begin{array}{l}\text { Decreased total cholesterol } \\
\text { and LDL \& liver enzymes }\end{array}$ & Arif et al. [81] \\
\hline & \multirow[b]{2}{*}{$1250 \mathrm{ppm}$} & \multirow[b]{2}{*}{ MOLM } & Increased serum HDL & \multirow[b]{2}{*}{ Ajantha et al. [120] } \\
\hline & & & $\begin{array}{l}\text { Decreased serum cholesterol, } \\
\text { LDL, triglyceride and muscle } \\
\text { cholesterol levels }\end{array}$ & \\
\hline & $90 \mathrm{~mL} / \mathrm{L}$ & MOLE & No effect & Kumar et al. [82] \\
\hline & \multirow[t]{2}{*}{$5 \%$} & \multirow[t]{2}{*}{ MOL } & $\begin{array}{l}\text { Lower WBC count and } \\
\text { lymphocyte \%age, glucose, } \\
\text { cholesterol, triglycerides, AST } \\
\text { and ALT concentrations. }\end{array}$ & \multirow[t]{2}{*}{ Hafsa et al. [83] } \\
\hline & & & $\begin{array}{l}\text { Higher heterophil and } \mathrm{H} / \mathrm{L} \\
\text { ratio, serum protein, } \mathrm{Ca} \text { and } \mathrm{P} \\
\text { levels }\end{array}$ & \\
\hline & \multirow{3}{*}{3,5 and $7 \mathrm{~g} / \mathrm{kg}$ diet } & \multirow{3}{*}{ MOLM } & $\begin{array}{l}\text { Increased blood constituents: } \\
\text { RBCs, Hb and PCV, WBCs, } \\
\text { plasma total protein, albumin, } \\
\text { Ca, HDL, GPX, GSH, SOD, } \\
\text { TAC, IgG, and T4 hormones }\end{array}$ & \multirow{3}{*}{ Ahmed and El-Rayes [64] } \\
\hline & & & $\begin{array}{c}\text { Decreased plasma cholesterol, } \\
\text { total lipids, LDL, AST, ALT } \\
\text { and glucose }\end{array}$ & \\
\hline & & & No effect on phosphorus (P) & \\
\hline
\end{tabular}

MOL: Moringa oleifera leaves MOLE: Moringa oleifera extract, MOLM: Moringa oleifera meal, MOLP: Moringa oleifera leaf powder.

M. oleifera leaf meal contains $86 \%$ dry matter, $22.5 \%$ crude fiber, $4.38 \%$ ether extract, $29.7 \%$ crude protein, $27.9 \%$ calcium, $0.26 \%$ phosphorus, and a very small quantity of tannin, according to estimates from one study [89]. It promotes immunity and has antibacterial properties [121]. M. oleifera contains anti-inflammatory, anticancer, antiulcer, and antioxidant effects within its various extracts and powder forms [122]. The M. oleifera leaf extracts show negligible or minimum toxicity levels and adverse effects in rabbits, rats, humans, 
and poultry [123]. Some of the examples of the uses of Moringa in poultry production and health are given in Figure 3.

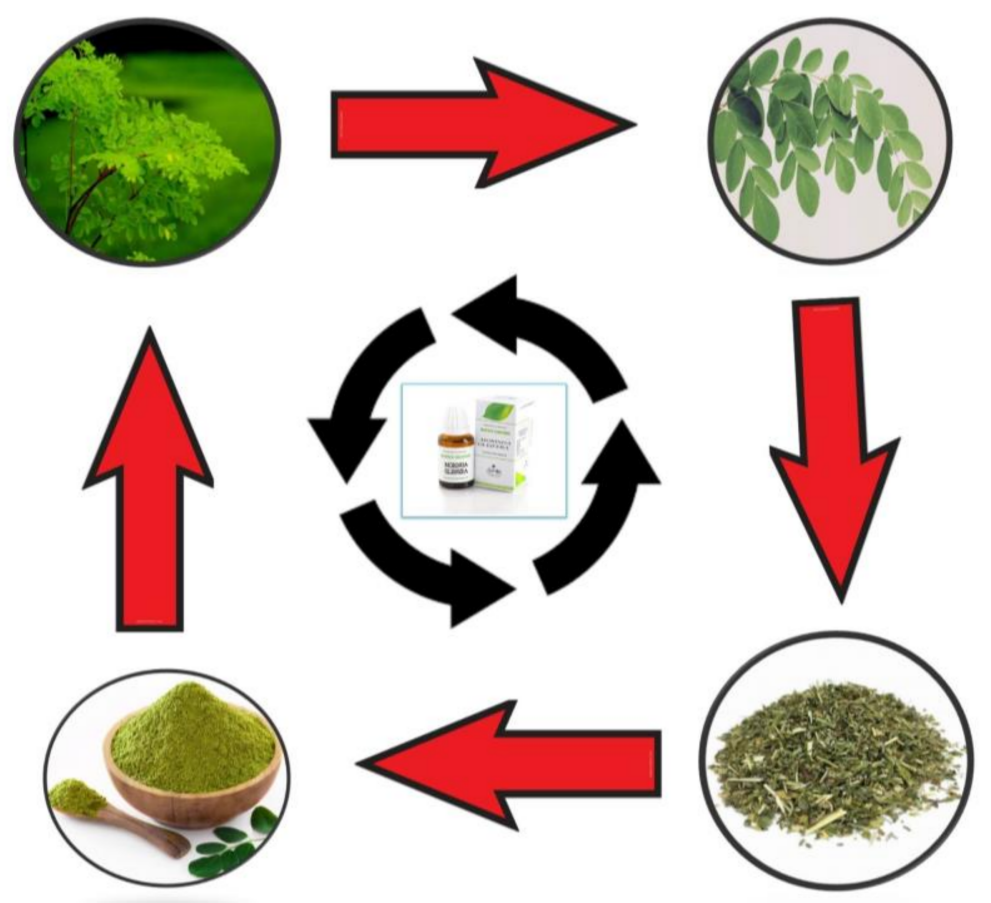

Figure 2. Main uses of Moringa: fresh, powder, as well as commercial preparations.

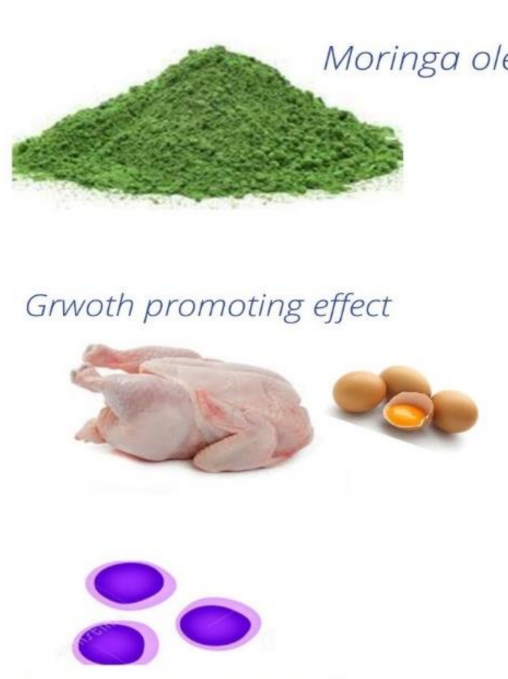

Immune modulating effect

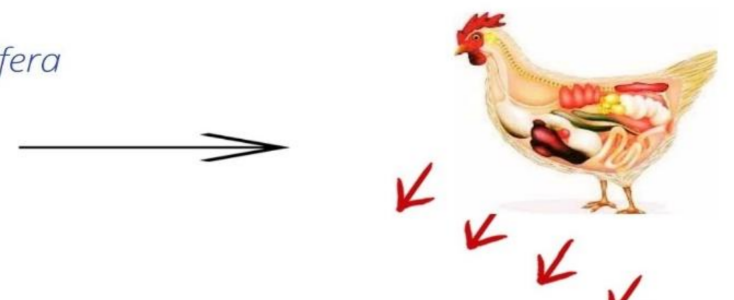

$K$

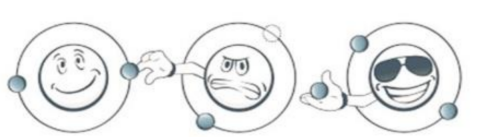

Antioxidnat effect

Anticoccidial effect

$$
000
$$

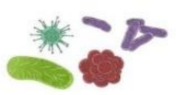

Antimicrobial effects

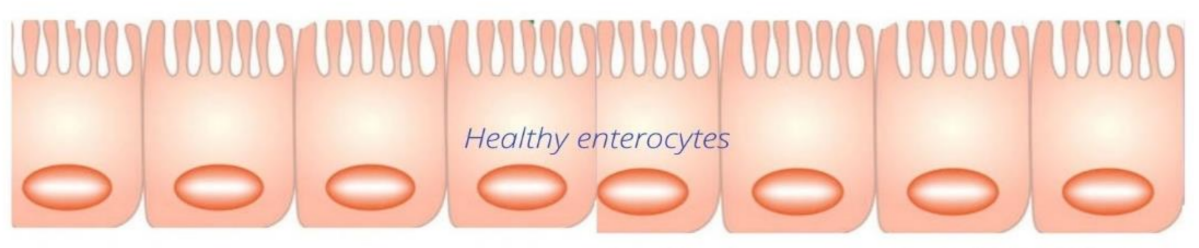

Figure 3. Example of some of the applications of M. oleifera in poultry diets.

\section{Feed Intake and Efficiency}

Recently, a number of authors have reported an improved feed intake in response to different doses and forms of M. oleifera [65-67]. According to Zanu et al. [88], the 
addition of Moringa meal reduced feed conversion efficiency considerably. Diets containing $0 \%, 2.5,5.0$ and $7.5 \%$ Moringa leaf meal had no significant influence on broiler chicken feed intake [73]. The birds which were fed diets with $750 \mathrm{~g} / 100 \mathrm{~kg}$ of Moringa leaf meal had the greatest feed-conversion ratio (FCR), which fell as the amount of Moringa leaf meal in the diet decreased. Paul et al. [75] concluded that the aqueous extract of the $M$. oleifera leaves reduced feed intake and enhanced the FCR in comparison with antibiotics in broiler chickens. According to El-Tazi et al. [61], using 5\% Moringa meal in the broiler diet boosted the feed intake and feed-conversion ratio considerably. However, Khan et al. [70] reported that M. oleifera leaf powder had no influence on the FCR or feed intake. Khan et al. [35] reported that $M$. oleifera leaf extract had no significant influence on the FCR or the feed intake, concluding that $M$. oleifera inclusion had no negative impact on broiler feed efficiency. M. oleifera had a substantial influence on the feed intake and the feed-conversion ratio, according to Alabi et al. [76], with improved FCR and lower feed intake in Moringa extract at $90 \mathrm{~mL} / \mathrm{L}$. According to Lu et al. [69], M. oleifera had no significant influence on feed intake, but did have a beneficial effect on the FCR. According to Kakengi et al. [87], less than 15\% Moringa incorporation in the diet of laying hens is advised without affecting the FCR. M. oleifera showed no significant influence on the feed intake and FCR, according to Ashour et al. [71]. At a level of 1-2\% of the basal diet, Kwariet et al. [86] reported no significant impacts on the feed-conversion ratio for M. oleifera leaf meal. In contrast to the control birds, Riry et al. [77] reported that feeding Japanese quail a diet containing 5\% M. oleifera seed meal resulted in a decrease in feed consumption. According to Elkloub et al. [78], Japanese quail which were given $0.2 \%$ M. oleifera leaf meal (MOLM) had the lowest feed consumption and the best feed-conversion ratio compared to those which were fed a control diet. Talukdar et al. [84] found that Japanese quail which were given

M. oleifera leaf meal (of 0.25 to $0.50 \%$ ) had a higher FCR than the control group that did not receive any supplementation. An improved FCR for Japanese quail which were given M. oleifera leaf meal at the rate of $0.1 \%$ was found by Kulkarni et al. [85]. Ahmed and El-Rayes [64] found that Japanese quail which were fed M. oleifera leaf meal at 3, 5, and $7 \mathrm{~g} / \mathrm{kg}$ in their diet had an increased FCR and feed intake when compared to the control group that did not receive any supplementation. According to Castillo et al. [72], there was a substantial increase in the FCR for Japanese quail which were given M. oleifera leaf flour at the concentration of 7,14 , and $21 \%$, but showed no significant change in feed consumption.

$M$. oleifera has a great capability of providing nutritional applications to humans and animal feedstuff, since it is an excellent source of fundamental contents, which may explain the enhanced feed intake and feed efficiency [51]. It can also be used as a growth stimulant [52]. The M. oleifera plant has more than 92 useful components, including 18 amino acids, according to some research [54]. According to Melesse et al. [124], broilers which were fed M. oleifera leaf meal showed a greater feed intake, possibly because of the enhanced bulkiness and decreased calorie content of the diet. According to Alabi et al. [125], the addition of Moringa meal reduced the feed consumption, which might be due to nutritional contentment. The decreased feed consumption might be due to Moringa having increased digestion and metabolic activities, which satisfy nutritional needs at a lower feed intake [126]. The decrease in feed intake might be attributable to a unique mix of phenolic chemicals found in M. oleifera leaves (zeatin, quercetin, kaempferol, and apigenin), which increase feed utilization and reduce the amount of feed required to satisfy the maintenance and production requirements [127].

However, there are discrepancies in the findings of feed intake and efficiency in M. oleifera supplemented birds. The reason could be due to the dose, duration, preparation of Moringa, in addition to strains of poultry and experimental design.

\section{Growth Performance and Body Weight Gain}

Body weight was usually found to be improved in response to the Moringa treatment, although instances of no improved effects have also been reported [65,80-82,92]. According to Zanu et al. [88], when Moringa leaf meal was added to the diet, the final body weight 
and mean body weight decreased dramatically. When Olugbemi et al. [90] incorporated Moringa leaf meal into cassava-based meals, they recorded a decrease in final weight and weight gain as the level of Moringa leaf meal increased. Nonetheless, Du et al. [93] found no significant reduction in the growth performance of broilers which were supplemented with $0.5,1.0,2.0$, and 3.0\% Moringa leaf meal. The broiler diets comprising more than 5-10\% leaf meals resulted in poor performance, according to Ash et al. [74]. When compared to the other experimental diets, El-Tazi et al. [61] found that the diet supplemented with 5\% Moringa meal resulted in the most significant body weight gain. Adding Moringa leaf meal to the broilers' feed boosted the weight gain in other studies $[90,91,128]$. The weight growth of the birds which were fed a meal containing 5\% Moringa meal was considerably greater in the chicks given Moringa-based diets, which performed much better than the control group birds according to Ebenebe et al. [62]. Khan et al. [70] found that supplementing with 1.2\% M. oleifera leaf powder raised the live body weight considerably. M. oleifera leaf powder had no effect on weight gain, according to Khan et al. [35]. Alabi et al. [76] reported that M. oleifera supplementation lowered bird growth rate and final body weight, which also had a substantial influence on the feed consumption and FCR. However, Lu et al. [69] and Hassan et al. [79] found that Moringa meal had a detrimental impact on broiler growth performance. The metrics of feed efficiency and body weight were enhanced by Morigna meal at 0.25 and $0.40 \%$, according to Avijit Dey and Partha Sarathi De [63]. According to Elkloub et al. [78], Japanese quail which were given $0.2 \%$ Moringa meal gained more weight than those which were fed a control diet. Talukdar et al. [84] found a substantial increase in weight gain in Japanese quail which were fed $M$. oleifera leaf meal at the rate of 0.25 to $0.50 \%$ compared to the control group that did not receive any supplementation. M. oleifera leaf meal, at a concentration of 0.25 to $0.50 \%$, can be utilized as a natural feed addition to increase the overall performance of Japanese quail. According to Kulkarni et al. [85], Japanese quail which were fed $M$. oleifera leaf meal at a rate of $0.1 \%$ gained significantly more weight than the control group. According to Ahmed and El-Rayes [64], when Japanese quail were fed $M$. oleifera leaf meal at 3, 5, and $7 \mathrm{~g} / \mathrm{kg}$ of their diet, a substantial increase in weight gain was found when compared to the control group that did not receive any supplementation. Castillo et al. [72] reported a substantial reduction in weight gain in Japanese quail which were given $M$. oleifera leaf flour at 7,14 , and $21 \%$.

Moringa leaves might be employed as a supplement in broiler diets to safely improve weight gain [129]. M. oleifera leaves have a high protein content of 25-27\%, making them an excellent protein source. Makkar and Becker [58] reported that the amino acid profiles of $M$. oleifera leaves and soya-bean meal are similar. M. oleifera leaves contain a high protein content on a dry matter basis, with all of the necessary amino acids of excellent quality [59]. The increased protein content and reduced amount of tannins, alkaloids, and glycosides in Moringa are efficiently digested and may result in the improved weight gain of birds [130]. The crude extract of M. oleifera, similar to other herbal medications, may have digestion-enhancing qualities, stimulating the growth of beneficial bacteria while suppressing the growth of harmful microbes, and therefore, influence poultry growth and intestinal microbiota [131]. The enhanced digestibility and absorption of nutrients from the intestine in Moringa meal supplemented birds might explain their higher body weight [63]. According to Abdulla et al. [132], the improved weight growth of birds which were fed Moringa diets might be attributed to the digestion stimulatory and gastroprotective properties. According to Ambali \& Furo [133], the pharmacological chemical components (cardiac glycosides, flavonoids, steroids, terpenes, saponins, and alkaloids) found in the M. oleifera extract may promote growth performance and body weight gain. Furthermore, carotenoids, phenolic chemicals, minerals, vitamins, alkaloids, flavonoids, and amino acids are abundant in $M$. oleifera leaves $[127,134]$. The high amount of vitamin C in M. oleifera, which can counteract the negative effects of heat stress and boost productive responses, may explain the improved performance in Moringa fed birds [79]. 


\section{Carcass Traits}

The leaves of M. oleifera are high in alpha-linoleic acid and a variety of important amino acids [55]. The high number of dietary antioxidants, such ascorbic acid and tocopherol, in M. oleifera may be responsible for the increase in carcass production [135]. These antioxidants reduce stress in birds while also enhancing protein absorption and digestion [136,137]. Mousa et al. [94] observed that food supplementation with M. oleifera increased carcass yield. El-Tazi [61] employed a variety of M. oleifera supplementation doses and found that a $5 \%$ supplementation in the diet boosted the carcass yield percentage when compared to the control group. Melesse et al. [95] found that increasing M. oleifera supplementation enhanced carcass yield. Tesfaye et al. [96] found that feeding M. oleifera leaf meal increased the dressing percentage, thighs, and drumstick weight significantly. Rao et al. [105] examined the varied food supplements of $M$. oleifera and concluded that M. oleifera had no influence on carcass yield. According to Zanu et al. [88], M. oleifera supplementation did not enhance dressing percentage. Carcass yield exhibited a substantial improvement in response to M. oleifera leaf extract [35]. According to Ahmed and El-Rayes [64], substantial increases in dressing weight were seen for Japanese quail which were fed M. oleifera leaf meal at rates of 3,5 , and $7 \mathrm{~g} / \mathrm{kg}$ within their food when compared to the control group that did not receive any supplementation. For Japanese quail fed with M. oleifera leaf flour at a rate of $14 \%$, Castillo et al. [72] found no significant influence on carcass weight and yield. The richness of M. oleifera in sources of carbohydrates, protein, and fiber, with minimal fat, might explain the rise in carcass weight. The availability of high pepsin and total soluble protein in M. oleifera leaf meal, which makes it a viable dietary protein source for simple non-ruminant animals, may explain the rise in carcass weight [128].

\section{Egg Production and Quality}

It was demonstrated that $M$. oleifera had a substantial influence on egg production and quality, as the M. oleifera supplemented group laid more eggs than the control group [108]. Lu et al. [69] concluded that $M$. oleifera supplementation at $15 \%$ had a significant influence on egg production, as the group treated with $15 \%$ M. oleifera produced less eggs. However, when the amount of M. oleifera increased, the egg quality in terms of yolk color and albumen height improved. When this meal was included at a $15 \%$ level in the diets, the egg production fell, while yolk rose [103]. Regardless of any antinutritional effects, the decrease in egg production might be linked to an increase in diet bulkiness as a result of rising of Moringa levels [97]. These findings suggest that Moringa meal could be added to the diets of laying hens at a rate of $15 \%$ in order to increase egg albumen quality and yolk color. Birds which were given Moringa at a 5\% concentration increased protein retention, which improved laying performance and egg quality [138]. Ashour et al. [71] found that dietary treatments with $M$. oleifera had no effect on hatchability, fertility and egg weight, or yolk index, but dramatically improved egg production, eggshell thickness, and egg mass. Kwariet et al. [86] reported no significant impacts on egg weight of Vanaraja laying chickens when $M$. oleifera leaf meal was added to the diet at a rate of $1-2 \%$ of the baseline diet. Olugbemi et al. [90] reported that replacing sunflower seed meal with Moringa leaf meal $(20 \%)$ in layer chicken diets resulted in a substantial drop in egg production and whole egg weight. According to Abdelnour et al. [102], Moringa usage of up to $10 \%$ showed no detrimental impacts on laying bird egg production, while levels larger than $10 \%$ had negative effects, probably due to the increased antinutritional components as well as low energy and protein digestibility. Talukdar et al. [84] found that quail egg quality features, such as egg weight and index of shape, albumen, and yolk, did not change; with the exception of yolk color, which exhibited a significantly greater value at the $1.00 \%$ level of Moringa. Yadav et al. [100] concluded that adding M. oleifera leaf meal into the diets of broiler and layer Japanese quail at a concentration of $1 \%$ can improve meat and egg quality and customer approval. 
The richness of $M$. oleifera in sources of carbohydrates, protein, and fiber, with minimal fat, might explain the rise in egg production and egg quality. The $M$. oleifera leaves contain a high protein content of $20-33 \%$ on a dry matter basis [59]. Increased egg production may be due to the high content of carotenoids, vitamins, minerals, amino acids, alkaloids, and flavonoids in the M. oleifera leaves [134], as well as a rare combination of phenolic compounds (quercetin, apigenin, kaempferol, and zeatin) that are essential for growth, resulting in less feed being needed to meet the birds' maintenance and production needs [127]. The high amount of vitamin $C$ in Moringa oleifera, which can counteract the negative effects of stress and boost productive responses, may explain the improved egg production and quality in the Moringa supplemented birds [79].

\section{Antioxidant Effects}

The presence of different vitamins ( $\mathrm{E}$ and $\mathrm{C}$ ) and minerals $(\mathrm{Cr}, \mathrm{Zn}$, and Se), which play an essential role in the activity of oxidative enzymes, might potentially explain the decrease in oxidative stress in animals [9,10,139-144]. It was reported that Moringa has over 92 useful components, including 46 antioxidants, 36 anti-inflammatory agents and 18 amino acids [54,145]. According to Balami et al. [104], malondialdehyde (MDA) concentrations decreased when Moringa meal supplementation was increased, decreasing the stress effect on birds. Rao et al. [105] concluded that $M$. oleifera reduces lipid peroxidation and thereby reduces stress in birds. According to Karthivashan et al. [106], the Moringa meal supplemented group had considerably lower MDA levels than the control group. According to Cui et al. [107], M. oleifera supplementation groups had lower MDA than the control groups. Ratshilivha et al. [108] reported the antioxidant properties of acetone extracts from $M$. oleifera, which were tested using the DPPH technique, with the findings presented in terms of the sample concentration reducing $50 \%$ of free radical scavenging (IC50). According to Khan et al. [35], stress levels in broilers exhibited a significant response to $M$. oleifera leaf extract supplementation when compared to the antibiotic group, as seen by lower blood MDA concentrations during the finisher phase. The lower plasma MDA levels might be attributable to M. oleifera's high content of antioxidants, such as tocopherol, ascorbic acids, flavonoids, and saponins. According to Elkloub et al. [78], Japanese quail which were given 0.4 and $0.6 \%$ Moringa meal had higher antioxidant activity than those on a control diet.

It is speculated that the presence of caffeic acid and cinnamic acid in M. oleifera gives it antioxidant qualities [53]. M. oleifera is high in dietary antioxidants, such as ascorbic acid and tocopherol, which help birds to cope with stress [136,137]. The oxidative stability of the oil derived from $M$. oleifera leaves was found to be very high, indicating the existence of natural antioxidants [103]. The flavonols, quercetin and kaempferol, in its 30-O-glycoside forms, are found in abundance in these leaves [52,97]. Flavonols are well-known chemicals that act as radical scavengers [138]. Furthermore, at equal molar concentrations, quercetin has been demonstrated to be a superior ABTS+ trap, with five times the activity of Trolox [102]. Similarly, cinnamic acid derivatives found in M. oleifera leaves are thought to provide various health advantages, including significant free radical scavenging characteristics, antibacterial activity, and antihyperglycemic activity [52,100,139]. According to Jung et al. [145] the gallic acid found in M. oleifera leaves, has antioxidant properties. The inclusion of glucosinolates, which have benzyl glycoside and hydrolyze to isothiocyanates, thiocyanates, or nitriles during enzymatic hydrolysis, boosts antioxidant activity in the $M$. oleifera leaves even more [52,146]. In lipopolysaccharide (LPS)-stimulated RAW264.7 murine macrophage cells, isothiocyanates were reported to decrease inducible nitric oxide synthase (iNOS) expression and nitric oxide generation [147]. Polyphenols were found in the aqueous extract of the $M$. oleifera leaves, according to Charoensin and Wongpoomchai [148]. M. oleifera leaves are also abundant in polyphenols and flavonoids, and, according to certain research also have antioxidant effects $[149,150]$. 


\section{Blood Biochemistry}

According to Zanu et al. [88], the M. oleifera supplemental food had a significant influence on triglycerides, low-density lipoprotein (LDL), very-low-density lipoprotein (VLDL), and plasma glucose concentrations, but not on blood parameters. Mahmood et al. [119] also found that M. oieifera supplementation lowered plasma glucose levels. The plasma protein increased with increasing levels of Moringa feed supplementation, according to Hassan et al. [79]. Teye et al. [151] came to the conclusion that increasing the concentration of Moringa meal supplementation enhanced plasma protein concentration. Apart from the mean corpuscular hemoglobin $(\mathrm{MCH})$, the other hematological indices were not substantially altered by M. oleifera feed supplementation, according to Du et al. [93], indicating that the meals were enough to fulfill the birds' nutrient demands. Khan et al. [35] reported that $M$. oleifera leaf extract had a substantial impact on mean blood glucose and protein concentrations, with lower serum glucose and higher serum protein concentrations during the finisher stages. According to Avijit Dey and Partha Sarathi De [63], Moringa supplementation induced a significant decrease in triglycerides, LDL-cholesterol, plasma total cholesterol, and a significant rise in HDL-cholesterol. Moringa, at a rate of $7.5 \%$, had a detrimental influence on blood fluctuations in terms of plasma albumen and globulin, according to Onu and Aniebo [130]. M. oleifera had a substantial impact in layers in response to Moringa supplementation in terms of increased aspartate aminotransferase (AST) activity and reduced uric acid content. According to Donsbough et al. [99], 15\% Moringa supplementation appears to have a deleterious effect on liver and renal function, as demonstrated by a greater AST activity and lower albumin and uric acid levels. Ashour et al. [71] found that blood AST and urea levels were lower in M. oleifera supplemented groups, while triglycerides and total cholesterol levels were also lower, with no significant effect on alanine aminotransferase (ALT), albumin, total protein, globulin, or the A/G ratio. Lu et al. [69] reported that Moringa leaf supplemented laying hens had lower albumen and urea concentrations than the control group. Elkloub et al. [78] concluded that different levels of Moringa (0.2, 0.4 and $0.6 \%$ ) decreased plasma ALT and AST and cholesterol in Japanese quail, however, total protein and globulin were increased. Ahmed and El-Rayes [64] concluded that significant increased red blood cells, white blood cells, hemoglobin, calcium, and thyroid hormones were found in Japanese quail which were fed with M. oleifera leaf meal at the rate of 3,5 and $7 \mathrm{~g} / \mathrm{kg}$ in their diet.

Little information is available on the mechanisms through which Moringa influences blood biochemistry. The drop in plasma glucose concentration may be related to $M$. oleifera's insulin-like action, which reduces gluconeogenesis and increases glucose consumption by cells [110]. M. oleifera has the capacity to enhance glucose absorption and use by body cells [149]. The lower plasma glucose concentrations may be linked to the regulation of hepatic gluconeogenesis and increased glucose use by body cells, which is one of the reasons Moringa supplementation improves dressing percentage [112,152]. The increased plasma protein concentration might be attributed to the large number of antioxidants found in Moringa, which have an inhibitory effect on corticosterone release, reducing protein catabolism under stressful situations and resulting in higher plasma protein concentrations [130].

\section{Antimicrobial Activity}

Moringa has been demonstrated to have antibacterial properties in several investigations. Bijal and Bhumika [109] demonstrated that the ethanol, methanol, petroleum ether, and aqueous extracts of the $M$. oleifera leaves have antimicrobial activities. The findings show that solvent extracts of $M$. oleifera components (leaves, flower, pulp, and seed) were effective against E. coli and S. aureus. M. oleifera leaf extracts have been proposed for use in the treatment of a variety of infectious disorders, either alone or in combination with other antibiotics [153]. The experiments conducted by Patel and Mohan [111] confirmed that different $M$. oleifera extracts inhibited different bacterial strains in different ways. Bacillus subtilis, Escherichia coli, Micrococcus luteus, Enterococcus faecalis, Klebsiella pneumoniae, Pseu- 
domonas aeruginosa, Bacillus cereus, Serratia marcescens, Staphylococcus epidermidis, Salmonella paratyphi, Staphylococcus aureus, and Salmonella typhi were among the species studied. Bichi and Shehu [154] used the agar-well diffusion technique in another recent investigation. The M. oleifera seed oil hexane crude extract showed strong antibacterial activity against E. coli, with average zones of inhibition of $17.7,14.3,11.3$, and $9.0 \mathrm{~mm}$ for the $100,75,50$, and $25 \%$ concentrations, respectively. According to Castillo et al. [72], M. oleifera leaf flour (14\%) substantially increased the immunity in Japanese quail by preventing both Gram-positive and Gram-negative bacterial growth.

Mohamed et al. [114] investigated the antiviral potential of M. oleifera leaf extracts. The antiviral test of the $M$. oleifera aqueous extract at a concentration of $200 \mathrm{~g} / \mathrm{mL}$ demonstrated inhibitory activity of 43.2 and $21.4 \%$ for herpes simplex virus types one and two, respectively. These findings show that $M$. oleifera can be used alone or in combination with viral medicines to treat viral infections. According to Mousa et al. [94], M. oleifera supplementation raised antibody titers against Newcastle disease (ND) and infectious bronchitis disease (IBD) in broiler chicks. M. oleifera supplementation boosted antibody titer against ND, according to Rao et al. [105]. Hassan et al. [79], on the other hand, found that increased $M$. oleifera supplementation lowered antibody titer against ND. According to Khan et al. [35], higher antibody titers against ND and infectious bronchitis (IB) were detected, indicating a substantial response to the $M$. oleifera leaf extract. The bioactive components of $M$. oleifera may increase the number of B lymphocytes, which are responsible for antibody production, resulting in a rise in antibody titer.

The mycelia growth of Aspergillus flavus was shown to be suppressed by M. oleifera (bark seed and leaf) crude extracts in a recent study by Aondo et al. [115]. M. oleifera's antifungal properties can help to prevent saprophytic fungi from contaminating the culture medium. The fungi were shown to be resistant to ethyl acetate, methanolic, ethanolic, and water extracts of M. oleifera leaves, seeds, and bark. According to Patel and Mohan [111], distinct extracts of $M$. oleifera demonstrated varied inhibitory patterns against different fungal strains in their testing.

The enhanced leucocyte production and bursal lymphocytes might be attributed to M. oleifera's antibacterial properties, which result in improved immunity [155]. The presence of diverse metabolites (chitinases, carboxylic acid, enzymes) and different lipophilic substances may possibly contribute to the increased antimicrobial action [156]. Due to the availability of natural immune modifying substances, including saponin and flavonoids, enhanced immunity was achieved by boosting lymphocytic cell growth [157]. In response to $M$. oleifera aqueous extract, the number of hematopoietic stem cells, B lymphocytes, naïve $\mathrm{T}$ cell expression, and proinflammatory cytokines increased [158,159]. Because of its exceptional medicinal and therapeutic properties, it may be used as a medication to prevent a variety of ailments [51,58]. It promotes immunity and has antibacterial properties [121]. M. oleifera exhibited antiulcer, anti-inflammatory, anticancer, and antioxidant effects in its various extract and powder forms [122].

Because the extract of Moringa contains a variety of compounds, all of which could trigger an immune response [155], Katanbaf et al. [160] stated that a rise in relative organ weight is seen as a sign of immunological progress. The birds in the Moringa supplemented groups were shown to be more energetic, fresh, and less vulnerable to prevalent diseases than the non-supplemented birds, which might be linked to the birds' higher antioxidant status [134]. The increase in immunity might be owing to the leaves of M. oleifera containing a unique mix of phenolic chemicals (zeatin, quercetin, kaempferol, and apigenin) that minimize disease infestation in the gastrointestinal tract [127]. According to Lannaon [161], heightened antimicrobial activity may be due to the presence of bioceutical compounds in the M. oleifera plant, as well as its bacterial and immune-stimulant activities [126]. The inclusion of antibacterial elements in Moringa might explain the increased antimicrobial activity [162]. Furthermore, methanol and n-hexane seed extracts from M. oleifera and M. stenopetala inhibited Salmonella typhi, Vibrio cholerae, and E. coli, which are known to 
cause water-borne illnesses [163]. M. oleifera leaves have a favorable effect on improving immunological responses and intestinal health in broilers, according to Olugbemi et al. [90].

\section{Anticoccidial Activity}

Fadunsin and Ademola [116] found that M. oleifera extract had a substantial inhibitory impact on the oocyst which were shed in the feces when compared to the control group, indicating that it might be a beneficial alternative product for the treatment of avian coccidiosis in chicken production. Herbal remedies may be an option for treating coccidiosis in chickens, with the drumstick tree (M. oleifera) showing promise. Banna et al. [117] found that adding $M$. oleifera powder $(0.5$ and $1 \%)$ to broiler feed was extremely effective in reducing coccidiosis symptoms associated with experimental infection with mixed Eimeria species and was comparable to diclazuril (1 ppm). According to Banna et al. [117], M. oleifera has a strong anticoccidial activity and may be a viable option for the prevention of avian coccidiosis in chicken production. In addition to its growth-promoting effect, safety, and antibacterial action, it may be used as a preventative and curative agent for coccidia. M. oleifera showed no significant influence on sporulation of Eimeria species oocysts in hens, according to Gadelhaq et al. [118]. The mechanism of anticoccidial activity, on the other hand, is yet unknown. It is suggested that the antioxidant capabilities of M. oleifera may be responsible for the suppression of the oocyst shed in feces. Antioxidant chemicals, according to Allen et al. [164], are known to lessen the severity of E. tenella infections by reducing the degree of intestinal lipid peroxidation.

\section{Conclusions}

Alternatives to antibiotics are used to reduce microbial populations and boost growth through a variety of mechanisms, including altering and/or inhibiting microbial growth, reducing inflammation, enhancing innate immunity, decreasing oxidative stress, and improving gut integrity. The most significant advancement in the hunt for genuine antibiotic alternatives is a better comprehension of new scientific information in order to produce unique products that can provide the benefits of antibiotics without increasing resistance. When considering phytochemicals as antibiotic alternatives, we must take into account the dosage, the differences the in active substances in plants, the toxic effects on various organs, the safety of the phytochemical leftovers in end-users, and the long-term effect of employing phytochemicals in chickens on resistance development. Although the use of phytochemicals is a relatively new topic of study, there is a need for a mechanistic approach to avoid misleading claims and to ensure safe commercialization and production. This will maximize good management and husbandry methods, with the ultimate objective of minimizing antibiotic usage in the animal industry. Understanding their mechanism of action, developing ways to standardize their effects, and refining delivery mechanisms for site-targeted distribution require further investigation. Based on the available evidence, we can conclude that including $M$. oleifera in poultry feed has positive effects on growth, blood biochemical profile, immunity, anticoccidial, antimicrobial, and antioxidant activity in the poultry industry, resulting in improved food safety, health, and economic aspects. However, it is pertinent to note that opinions are divided on the beneficial outcome of M. oleifera supplementation in poultry. It seems that the beneficial effects of this plant are linked with preparation, dose level, duration of supplementation and other experimental variations. In addition, little attention has been given to the mechanism of action through which $M$. oleifera produces such beneficial impacts in poultry.

Author Contributions: R.U.K., A.K. and S.N. designed the study; R.U.K., A.K., S.N. and Q.U. wrote the article; R.U.K., V.L., V.T. and M.R. critically reviewed, edited, and submitted the paper. All authors have read and agreed to the published version of the manuscript.

Funding: This research received no external funding.

Acknowledgments: The authors would like to extend their sincere appreciation to the lab technicians involved in this study. 
Conflicts of Interest: The authors declare no conflict of interest.

\section{References}

1. Gould, I.M. Antibiotic policies to control hospital-required infection. J. Antimicrob. Chemother. 2008, 61, 763-765. [CrossRef]

2. Donoghue, D.J. Antibiotic residues in poultry tissues and eggs: Human health concerns. Poultry Sci. 2003, 82, 618-621. [CrossRef]

3. Khan, R.U.; Rahman, Z.U.; Javed, I.; Muhammad, F. Effects of vitamins, probiotics and protein level on semen traits and some seminal plasma macro and micro minerals of male broiler breeders after zinc-induced molting. Biol. Trace Elem. Res. 2012, 148, 44-52. [CrossRef] [PubMed]

4. Khan, R.U.; Rahman, Z.U.; Javed, I.; Muhammad, F. Effect of vitamins, probiotics and protein on semen traits in post-molt male broiler breeders. Anim. Reprod. Sci. 2012, 135, 85-90. [CrossRef] [PubMed]

5. Khan, R.U.; Naz, A.S. Applications of probiotics in poultry production. World's Poult. Sci. J. 2013, 69, 621-632. [CrossRef]

6. Khan, R.U.; Rahman, Z.U.; Javed, I.; Muhammad, F. Supplementation of vitamins, probioitics and proteins on oxidative stress, enzymes and hormones in post-moulted male broiler breeder. Arch. Tierz. 2013, 61, 607-616.

7. Khan, R.U.; Rahman, Z.U.; Javed, I.; Muhammad, F. Supplementation of dietary vitamins, protein and probiotics on semen traits and immunohistochemical study of pituitary hormones in zinc-induced molted broiler breeders. Acta Histochem. 2013, 115, 698-704. [CrossRef]

8. Alam, S.; Masood, S.; Zaneb, H.; Rabbani, I.; Khan, R.U.; Shah, M.; Ashraf, S.; Alhidary, I.A. Effect of Bacillus cereus and phytase on the expression of musculoskeletal strength and gut health in Japanese quail (Coturnix japonica). Poult. Sci. J. 2020, 57, 200-204. [CrossRef]

9. Shah, M.; Zaneb, H.; Masood, S.; Khan, R.U.; Mobashar, M.; Khan, I.; Din, S.; Khan, M.S.; Rehman, H.; Tinelli, A. Single or combined applications of zinc and multi-strains probiotic on intestinal histomorphology of broilers under cyclic heat stress. Probiotics Antimicrob. Proteins 2020, 12, 473-480. [CrossRef] [PubMed]

10. Shah, M.; Zaneb, H.; Masood, S.; Khan, R.U.; Ashraf, S.; Sikandar, A.; Rehman, H.F.U.; Rehman, H. Effect of dietary supplementation of zinc and multi-microbe probiotic on growth traits and alteration of intestinal architecture in broiler. Probiotics Antimicrob. Proteins 2019, 11, 931-937. [CrossRef]

11. Chand, N.; Faheem, H.; Khan, R.U.; Qureshi, M.S.; Alhidary, I.A.; Abudabos, A.M. Anticoccidial effect of mannanoligosacharide against experimentally induced coccidiosis in broiler. Environ. Sci. Pollut. Res. 2016, 23, 14414-14421. [CrossRef]

12. Chand, N.; Khan, R.U.; Mobashar, M.; Naz, S.; Rowghani, I.; Khan, M.A. Mannanoligosaccharide (MOS) in broiler ration during the starter phase: 1. growth performance and intestinal histomorphology. Pak. J. Zool. 2019, 51, 173-176. [CrossRef]

13. Tufail, M.; Chand, N.; Rafiullah, A.S.; Khan, R.U.; Mobashar, M.; Naz. S. Mannanoligosaccharide (MOS) in broiler diet during the finisher phase: 2. growth traits and intestinal histomorphology. Pak. J. Zool. 2019, 51, 597-602. [CrossRef]

14. Haq, I.; Hafeez, A.; Khan, R.U. Protective effect of Nigella sativa and Saccharomyces cerevisiae on zootechnical characteristics, fecal Escherichia coli and hematopoietic potential in broiler infected with experimental Colibacillosis. Livest. Sci. 2020, $239,104119$. [CrossRef]

15. Abd El-Hack, M.; Alagawany, M.; Arif, M.; Emam, M.; Saeed, M.; Arain, M.A.; Siyal, F.A.; Patra, A.; Elnesr, S.S.; Khan, R.U. The uses of microbial phytase as a feed additive in poultry nutrition-A review. Ann. Anim. Sci. 2018, 18, 639-658. [CrossRef]

16. Sultan, A.; Ali, R.; Khan, R.U.; Khan, S.; Chand, N.; Tariq, A. Nutritional evaluation of two sorghum varieties in broiler fortified with phytase. Pak. J. Zool. 2019, 51, 1183-1185. [CrossRef]

17. Jabbar, A.; Tahir, M.; Alhidary, M.A.; Abdelrahman, M.; Albaadani, H.; Khan, R.U.; Selvaggi, M.; Laudadio, V.; Tufarelli, V. Impact of Microbial Protease Enzyme and Dietary Crude Protein Levels on Growth and Nutrients Digestibility in Broilers over 15 to 28 days. Animals 2021, 11, 2499. [CrossRef]

18. Jabbar, A.; Tahir, M.; Khan, R.U.; Ahmad, N. Interactive effect of exogenous protease enzyme and dietary crude protein levels on growth and digestibility indices in broiler chickens during the starter phase. Trop. Anim. Health Prod. 2021, 53, 1-5. [CrossRef]

19. Khan, R.U.; Chand, N.; Ali, A. Effect of organic acids on the performance of Japanese quails. Pak. J. Zool. 2016, 48, 1799-1803.

20. Abudabos, A.M.; Alyemni, A.H.; Dafalla, Y.M.; Khan, R.U. Effect of organic acid blend and Bacillus subtilis alone or in combination on growth traits, blood biochemical and antioxidant status in broiler exposed to Salmonella typhimurium challenge during the starter phase. J. Appl. Anim. Res. 2017, 45, 538-542. [CrossRef]

21. Khan, R.U.; Nikosefat, Z.; Tufarelli, V.; Naz, S.; Javdani, M.; Laudadio, V. Garlic (Allium sativa) supplementation in poultry diet: Effect on production and physiology. World's Poult. Sci. J. 2012, 68, 417-424. [CrossRef]

22. Khan, R.U.; Naz, S.; Nikousefat, Z.; Tufarelli, V.; Laudadio, V. Thymus vlugaris: Alternative to antibiotics in poultry feed. World's Poult. Sci. J. 2012, 68, 401-408. [CrossRef]

23. Khan, R.U.; Naz, S.; Tufarelli, V.; Laudadio, V. Potential applications of ginger (Zingiber officinale) in poultry diet. World's Poult. Sci. J. 2012, 68, 245-252. [CrossRef]

24. Khan, R.U.; Naz, S.; Javadani, M.; Nikousefat, Z.; Selvaggi, M.; Tufarelli, V.; Laudadio, V. The use of turmeric (Curcuma longa) in poultry diets. World's Poult. Sci. J. 2012, 68, 97-103. [CrossRef]

25. Dhama, K.; Latheef, S.K.; Mani, S.; Samad, H.A.; Karthik, K.; Tiwari, R.; Khan, R.U.; Alagawany, M.; Farag, M.R.; Alam, G.M.; et al. Multiple beneficial applications and modes of action of herbs in poultry health and production- A review. Int. J. Pharmacol. 2015, 11, 152-176. [CrossRef] 
26. Alzawqari, M.H.; Al-Baddany, A.A.; Al-Baadani, H.H.; Alhidary, I.A.; Khan, R.U.; Aqil, G.M.; Abdurab, A. Effect of feeding dried sweet orange (Citrus sinensis) peel and lemon grass (Cymbopogon citratus) leaves on growth performance, carcass traits, serum metabolites and antioxidant status in broiler during the finisher phase. Environ. Sci. Pollut. Res. 2016, 23, 17077-17082. [CrossRef] [PubMed]

27. Hafeez, A.; Sohail, M.; Ahmad, A.; Shah, M.; Din, S.; Khan, I.; Shuib, M.; Nasrullah; Shahzada, W.; Iqbal, M.; et al. Selected herbal plants showing enhanced growth performance, ileal digestibility, bone strength and blood metabolites in broilers. J. Appl. Anim. Res. 2020, 48, 448-453. [CrossRef]

28. Hafeez, A.; Ullah, Z.; Khan, R.U.; Ullah, Q.; Naz, S. Effect of diet supplemented with essential coconut oil on performance and intestinal injury in broiler exposed to avian coccidiosis. Trop. Anim. Health Prod. 2020, 52, 2499-2504. [CrossRef]

29. Hafeez, A.; Shah, S.A.A.; Khan, R.U.; Ullah, Q.; Naz, S. Effect of diet supplemented with phytogenics and protease enzyme on performance, serum biochemistry and muscle histomorphology in broilers. J. Appl. Anim. Res. 2020, 48, 326-330. [CrossRef]

30. Shuaib, M.; Nasrullah; Hafeez, M.; Alhidary, I.; Abdelrahman, M.; Khan, R.U. Effect of dietary supplementation of wildCumin (Bunium persicum) seeds on performance, nutrient digestibility and circulating metabolites in broiler chicks during the finisher phase. Anim. Biotechnol. 2021, in press. [CrossRef]

31. Shuaib, M.; Nasrullah; Hafeez, A.; Alhidary, I.A.; Abdelrahman, M.M.; Khan, N.U.; Khan, R.U. Dietary fortification of crushed seeds of Bonium persicum on growth performance, apparent ileal digestibility and blood metabolites in broiler chicks during the starter phase. Ital. J. Anim. Sci. 2021, 20, 1-5. [CrossRef]

32. Ahmad, Z.; Hafeez, A.; Ullah, Q.; Naz, S.; Khan, R.U. Protective effect of Aloe vera on growth performance, leucocyte count and intestinal injury in broiler chicken infected with coccidiosis. J. Appl. Anim. Res. 2020, 48, 252-256. [CrossRef]

33. Chand, N.; Ali, P.; Alhidary, I.A.; Abelrahman, M.M.; Albadani, H.; Khan, M.A.; Seidavi, A.; Laudadio, V.; Tufarelli, V.; Khan, R.U. Protective Effect of grape (Vitis vinifera) seed powder and zinc-glycine complex on growth traits and gut health of broilers following Eimeria tenella challenge. Antibiotics 2021, 10, 186. [CrossRef] [PubMed]

34. Israr, M.; Chand, N.; Khan, R.U.; Alhidary, I.A.; Abdelrhman, M.M.; Al-Baddani, H.H.; Laudadio, V.; Tufarelli, V. Dietary grape (Vitis vinifera) seeds powder and organic Zn-gly chelate complex for mitigating heat stress in broiler chickens: Growth parameters, malanodialdehyde, paraoxonase-1 and antibody titre. Agriculture 2021, 11, 1087. [CrossRef]

35. Khan, A.; Tahir, M.; Alhidary, I.; Abdelrahman, M.; Swelum, A.A.; Khan, R.U. Role of dietary Moringa oleifera leaf extract on productive parameters, humoral immunity and lipid peroxidation in broiler chicks. Anim. Biotechnol. 2021, 1-6. [CrossRef]

36. Dhama, K.; Karthik, K.; Khandia, R.; Munjal, A.; Tiwari, R.; Rana, R.; Khurana, S.K.; Sana, U.; Khan, R.U.; Alagawany, M.; et al. Medicinal and therapeutic potential of herbs and plant metabolites/extracts countering viral pathogens-Current knowledge and future prospects. Curr. Drug Metab. 2018, 19, 236-263. [CrossRef] [PubMed]

37. Rahman, Z.; Naz, S.; Khan, R.U.; Tahir, M. An update on the potential application of L-carnitine in poultry. World's Poult. Sci. J. 2017, 73, 823-830. [CrossRef]

38. Chand, N.; Khan, R.U.; Shah, M.; Naz, S.; Tinelli, A. Zinc source modulates zootechnical characteristics, intestinal features, humoral response and paraoxonase (PON1) activity in broilers. Trop. Anim. Health Prod. 2020, 52, 511-515. [CrossRef]

39. Khan, R.U.; Durrani, F.R.; Chand, N. Influence of feed supplementation with Cannabis sativa on quality of broilers carcass. Pak. Vet. J. 2010, 30, 34-38.

40. Mushtaq, M.; Naz, S.; Khan, S.; Rahman, S.; Khan, R.U. In vivo effect of Berberis lyceum and Silybum marianum on production performance and immune status in broiler chicks. Arch. Tierz. 2013, 56, 911-916.

41. Safiullah; Chand, N.; Khan, R.U.; Naz, S.; Ahmad, M.; Gul, S. Effect of ginger (Zingiber officinale Roscoe) and organic selenium on growth dynamics, blood melanodialdehyde and paraoxonase in broilers exposed to heat stress. J. Appl. Anim. Res. 2019, 47, 212-216. [CrossRef]

42. Tanweer, A.J.; Chand, N.; Saddique, U.; Bailey, C.A.; Khan, R.U. Antiparasitic effect of wild rue (Peganum harmala L.) against experimentally induced coccidiosis in broiler chicks. Parasitol. Res. 2014, 113, 2951-2960. [CrossRef]

43. Tehseen, M.; Tahir, M.; Khan, R.U.; Jabbar, A.; Ahmad, B.; Ahsan, T.; Khan, S.; Abudabos, A.M. Additive effect of Nigella sativa and Zingiber officinale herbal mixture on performance and cholesterol profile in broiler. Philipp. Agric. Sci. 2016, 99, 408-413.

44. Raza, T.; Chand, N.; Khan, R.U.; Shahid, M.S.; Abudabos, A.M. Improving the fatty acid profile in egg yolk through the use of hempseed (Cannabis sativa), ginger (Zingiber officinale), and turmeric (Curcuma longa) in the diet of Hy-Line White Leghorns. Arch. Anim. Breed. 2016, 68, 183-190. [CrossRef]

45. Abudabos, A.M.; Alyemni, A.H.; Dafalla, Y.M.; Khan, R.U. The effect of phytogenics on growth traits, blood biochemical and intestinal histology in broiler chickens exposed to Clostridium perfringens challenge. J. Appl. Anim. Res. 2018, 46, 691-695. [CrossRef]

46. Abudabos, A.M.; Alyemni, A.H.; Dafallah, Y.M.; Khan, R.U. The effect of phytogenic feed additives to substitute in-feed antibiotics on growth traits and blood biochemical parameters in broiler chicks challenged with Salmonella typhimurium. Environ. Sci. Pollut. Res. 2016, 23, 24151-24157. [CrossRef]

47. Wahab, F.; Chand, N.; Khan, R.U.; Ahmad, N.; Pervez, U.; Ur-Rehman, Z.; Naz, S. Dietary supplementation of Fenugreek (Trigonella foenum graecum) on the egg quality characteristics of Rhode Island Red spent layers. Pak. J. Zool. 2019, 51, $1793-1797$. [CrossRef] 
48. Ahmad, M.; Chand, N.; Khan, R.U.; Ahmad, N.; Khattak, I.; Naz, S. Dietary supplementation of milk thistle (Silybum marianum): Growth performance, oxidative stress and immune response in natural summer stressed broilers. Trop. Anim. Health Prod. 2020, 52, 711-715. [CrossRef] [PubMed]

49. Lowel, J.F. Introduction to Moringa Family; Church World Service: Dakar, Senegal, 2001.

50. Fuglie, L.J. The Miracle Tree: Moringa oleifera: Natural Nutrition for the Tropics; Church World Service: Dakar, Senegal, 1999 ; p. 68.

51. Francis, G.; Makkar, H.P.S.; Becker, K. Dietary supplementation with a Quillaja saponin mixture improves growth performance and metabolic efficiency in common carp (Cyprinus carpio L.). Aquaculture 2002, 203, 311-320. [CrossRef]

52. Mbikay, M. Therapeutic potential of Moringa oleifera leaves in chronic hyperglycemia and dyslipidemia: A Review. Front. Pharmacol. 2012, 3, 1-12. [CrossRef] [PubMed]

53. Cowan, M.M. Plant products as antimicrobial agents. Clin. Microbiol. Rev. 1999, 12, 564-582. [CrossRef]

54. Nnam, N.M. Moringa oleifera leaf improves iron status of infants 6-12 months in Nigeria. Int. J. Food Saf. Nutr. Public Health 2009, 2, 158-164. [CrossRef]

55. Moyo, B.; Masika, P.J.; Hugo, A.; Muchenj, V. Nutritional characterization of Moringa (Moringa oleifera Lam.) leaves. Afr. J. Biotechnol. 2011, 10, 12925-12933.

56. Aja, P.M.; Ibiam, U.A.; Uraku, A.J.; Orji, O.U.; Offor, C.E.; Nwali, B.U. Comparative Proximate and Mineral Composition of Moringa oleifera Leaf and Seed. Glob. Adv. Res. J. Agric. Sci. 2013, 2, 137-141.

57. Sobhy, A.E.; Gamal, M.H.; Sameh, E.M.; Mohamed, H.A.; Rashad, R.A. Biochemical and functional properties of Moringa oleifera leaves and their potential as a functional food. Glob. Adv. Res. J. Agric. Sci. 2015, 4, 188-199.

58. Makkar, H.P.S.; Becker, K. Nutrients and antiquality factors in different morphological parts of the Moringa oleifera tree. J. Agri. Sci. 1997, 128, 311-322. [CrossRef]

59. Foidl, N.; Paull, R. Moringa oleifera. In The Encyclopedia of Fruit and Nuti; ABI: Oxfordshire, UK, 2008; pp. 509-512.

60. Loren, L. Moringa oleifera Malnutrition Relief. Filipino Senator, Wikipedia, the Free Encyclopedia. 2007. Available online: http://taggedwiki.zubiaga.org/new_content/11c308c223310d6ff7651787102f1e8c (accessed on 3 March 2021).

61. El-Tazi, S.M. Effect of feeding different levels of Moringa oleifera leaf meal on the performance and carcass quality of broiler chicks. Int. J. Sci. Res. 2014, 3, 147-151.

62. Ebenebe, C.I.; Anigbogu, C.C.; Anizoba, M.A.; Ufele, A.N. Effect of various levels of Moringa leaf meal on the egg quality of ISA Brown breed of layers. J. Adv. Life Sci. Technol. 2013, 14, 45-49.

63. Dey, A.; De, P.S. Influence of Moringa oleifera leaves as a functional feed additive on the growth performance, carcass characteristics and serum lipid profile of broiler chicken. Indian J. Anim. Res. 2013, 47, 449-452.

64. Ahmed, W.F.; El-Rayes, T.K. Effect of using Moringa oleifera leaves on productive performance and some physiological parameters of japanese quail. Egypt. Poult. Sci. J. 2019, 39, 193-205. [CrossRef]

65. Mikhail, W.Z.; Abd El-Samee, M.O.; El-Afifi, T.M.; Mohammed, A.R. Effect of feeding Moringa oleifera leaf meal with or without enzyme on the performance and carcass characteristics of broiler chicks. Plant Arch. 2020, 20, 3381-3388.

66. Tekce, E.; Bayraktar, B.; Aksakal, V.; Dertli, E.; Kamiloğlu, A.; Çinar Topcu, K.; Kaya, H. Response of Japanese quails (Coturnix coturnix japonica) to dietary inclusion of Moringa oleifera essential oil under heat stress condition. Ital. J. Anim. Sci. 2020, 19, 514-523. [CrossRef]

67. Abou-Elkhair, R.; Abdo Basha, H.; Slouma Hamouda Abd El Naby, W.; Ajarem, J.S.; Maodaa, S.N.; Allam, A.A.; Naiel, M.A.E. Effect of a diet supplemented with the seed powder on the performance, egg quality, and gene expression in Japanese laying quail under heat-stress. Animals 2020, 10, 809. [CrossRef]

68. Egu, U.N. Effect of graded levels of Moringa oleifera leaf meal on performance and serum biochemical parameters of broiler chickens. J. Anim. Sci. Vet. Med. 2019, 4, 1-8. [CrossRef]

69. Lu, W.; Wang, J.; Zhang, H.J.; Wu, S.G.; Qi, G.H. Evaluation of Moringa oleifera leaf in laying hens: Effects on laying performance, egg quality, plasma biochemistry and organ histopathological indices. Ital. J. Anim. Sci. 2016, 15, 658-665. [CrossRef]

70. Khan, I.; Zaneb, H.; Masood, S.; Yousaf, M.S.; Rehman, H.F.; Rehman, H. Effect of Moringa oleifera leaf powder supplementation on growth performance and intestinal morphology in broiler chickens. J. Anim. Physiol. Anim. Nutr. 2017, 101, 114-121. [CrossRef]

71. Ashour, E.A.; El-Kholy, M.S.; Alagawany, M.; El-Hack, A.; Mohamed, E.; Mohamed, L.A.; Tufarelli, V. Effect of dietary supplementation with Moringa oleifera leaves and/or seeds powder on production, egg characteristics, hatchability and blood chemistry of laying Japanese quails. Sustainability 2020, 12, 2463. [CrossRef]

72. Castillo, L.R.I.; Portillo, L.J.J.; León, F.J.; Gutiérrez, D.R.; Angulo, E.M.A.; Muy-Rangel, M.D.; Heredia, J.B. Inclusion of Moringa leaf powder (Moringa oleifera) in fodder for feeding japanese quail (Coturnix coturnix japonica). Braz. J. Poult. Sci. 2018, 20, 15-26. [CrossRef]

73. Atuahene, C.C.; Attoh-Kotoku, V.; Fosu, K.D.; Amissah, S.E.; Sarfo, F.K.; Mensah, J.J. Preliminary study of the effect of feeding Moringa oleifera leaf meal as a feed ingredient on the growth performance of broiler chickens. In Proceedings of the 28th and 29th Ghana Animal Science Association held at the University of Education, Winneba, Mmpong Campus, 9 August 2008; University Press: Winneba, Ghana, 2010; pp. 72-75.

74. Ash, A.J.; Petaia, L.; Ako, H. Nutritional value of Sesbania grandiflora leaves for monogastric and ruminants. Trop. Agric. 1992, $69,223-228$. 
75. Paul, T.K.; Sarker, Y.A.; Tarafder, M.; Rimon, M.A.; Haque, M.A.; Sikder, M.H. Water supplementation of Moringa oleifera as a substitute for antibiotics on performance and blood parameters of broiler chickens. J. Bangladesh Agric. Univ. 2018, 16, 266-270. [CrossRef]

76. Alabi, O.J.; Malik, A.D.; Ng'ambi, J.W.; Obaje, P.; Ojo, B.K. Effect of aqueous Moringa oleifera (Lam) leaf extracts on growth performance and carcass characteristics of Hubbard broiler chicken. Braz. J. Poult. Sci. 2017, 19, 273-280. [CrossRef]

77. Riry, F.H.; Elkloub, K.; Moustafa, M.E.L.; Mousa, M.A.M.; Youssef, S.F.; Hanan, A.H. Effect of using Moringa oleifera seed meal on Japanese quail performance during growing period. In Proceedings of the 9th International Poultry Conference, Hurghada, Egypt, 7-10 November 2016; pp. 322-337.

78. Elkloub, K.; Moustafa, M.E.L.; Riry, F.H.; Mousa, M.A.M.; Hanan, A.H.; Youssef, S.F. Effect of using Moringa oleifera leaf meal on performance of Japanese quail. Egypt. Poult. Sci. J. 2015, 35, 1095-1108.

79. Hassan, H.M.A.; El-Moniary, M.M.; Hamouda, Y.; El-Daly, E.F.; Youssef, A.W.; Abd El-Azeem, N.A. Effect of different levels of Moringa oleifera leaves meal on productive performance, carcass characteristics and some blood parameters of broiler chicks reared under heat stress conditions. Asian J. Anim. Vet. Adv. 2016, 11, 60-66. [CrossRef]

80. Wahab, O.A.A.; Sobhy, H.M.; Badr, A.M.; Ghazalah, A.A. Effect of Moringa oleifera seeds powder on performance and immunity of broiler chicks. AIMS Agric. Food 2020, 5, 896-910. [CrossRef]

81. Arif, M.; Hayat, Z.; Abd El-Hack, M.E.; Saeed, M.; Imran, H.M.; Alowaimer, A.N.; Swelum, A.A. Impacts of supplementing broiler diets with a powder mixture of black cumin, Moringa and chicory seeds. S. Afr. J. Anim. Sci. 2019, 49, 564-572. [CrossRef]

82. Kumar, R.; Kumar, K.; Kumar, A.; Kumar, S.; Singh, P.K.; Sinha, R.R.K.; Moni, C. Nutritional and physiological responses of broiler chicken to the dietary supplementation of Moringa oleifera aqueous leaf extract and ascorbic acid in tropics. Trop. Anim. Health Prod. 2021, 53, 1-7. [CrossRef]

83. Hafsa, S.H.; Ibrahim, S.A.; Eid, Y.Z.; Hassan, A.A. Effect of dietary Moringa oleifera leaves on the performance, ileal microbiota and antioxidative status of broiler chickens. J. Anim. Physiol. Anim. Nutr. 2020, 104, 529-538. [CrossRef]

84. Talukdar, A.; Kalita, K.P.; Saikia, R.; Choudhury, D. Effect of using Moringa oleifera leaf meal on quality and sensory parameters of Japanese quail eggs. Pharma Innov. J. 2020, 9, 219-221.

85. Kulkarni, R.C.; Durge, S.M. Dietary Inclusion of Moringa oleifera Leaf Meal Improved Production Performance and Reduced Cost of Production in Japanese Quail. J. Poult. Sci. 2019, 7, 66-70.

86. Kwariet, I.; Diarra, S.; Raji, A.; Adamu, S. Egg production and egg quality of laying hens fed raw or processed sorrel (Hibiscus sabdariffa) seed meal. Agric. Biol. J. N. Am. 2011, 2, 616-621. [CrossRef]

87. Kakengi, A.M.V.; Kaijage, J.; Sarwatt, S.; Mutayoba, S.K.; Shem, M.N.; Fujihara, T. Effect of Moringa oleifera leaf meal as a substitute for sunflower seed meal on performance of laying hens in Tanzania. Bone 2007, 19, 446.

88. Zanu, H.K.; Asiedu, P.; Tampuori, M.; Abada, M.; Asante, I. Possibilities of using Moringa (Moringa oleifera) leaf meal as a partial substitute for fishmeal in broiler chickens diets. Online J. Anim. Feed Res. 2012, 2, 70-75.

89. Kakengi, A.M.V.; Shen, M.N.; Sarwart, S.V.; Fujihara, T. Can Moringa oleifera be used as protein supplement to ruminant diet. Asian-Aust. J. Anim. Sci. 2003, 18, 42-47. [CrossRef]

90. Olugbemi, T.S.; Mutayoba, S.K.; Lekule, F.P. Effect of Moringa (Moringa oleifera) inclusion in cassava based diets fed to broiler chickens. Int. J. Poult. Sci. 2010, 9, 363-367. [CrossRef]

91. Banjo, O.S. Growth and performance as affected by inclusion of Moringa oleifera leaf meal in broiler chicks diet. J. Biol. Agric. Healthc. 2012, 2, 35-38.

92. Kilany, O.E.; Youssef, F.; Mabrouk, M.; Fares, I.M. Clinicopathological studies on the effect of some antibacterial medicinal plants in broilers. J. Clin. Pathol. Forecast. 2018, 1, 1003.

93. Du, P.L.; Lin, P.H.; Yang, R.Y.; Fan, Y.K.; Hsu, J.C. Effects of dietary supplementation of Moringa oleifera on growth performance, blood characteristics and immune response in broilers. J. Chin. Soc. Anim. Sci. 2007, 36, 135-146.

94. Mousa, M.A.; Osman, A.S.; Hady, H.A. Performance, immunology and biochemical parameters of Moringa oleifera and/or Cichorium intybus addition to broiler chicken ration. J. Vet. Med. Anim. Health 2017, 9, 255-263.

95. Melesse, A.; Tiruneh, W.; Negesse, T. Effects of feeding Moringa stenopetala leaf meal on nutrient intake and growth performance of Rhode Island Red chicks under tropical climate. Trop. Subtrop. Agroecosystems 2011, 14, 485-492.

96. Tesfaye, E.; Animut, G.; Urge, M.; Dessie, T. Moringa olifera leaf meal as an alternative protein feed ingredient in broiler ration. Int. J. Poult. Sci. 2013, 12, 289-297. [CrossRef]

97. Onunkwo, D.N.; George, O.S. Effects of Moringa oleifera leaf meal on the growth performance and carcass characteristics of broiler birds. J. Agric. Vet. Sci. 2015, 8, 63-66.

98. Mohammed, K.A.E.F.; Sarmiento-Franco, L.; Santos-Ricalde, R.; Solorio-Sanchez, J.F. The nutritional effect of Moringa oleifera fresh leaves as feed supplement on Rhode Island Red hen egg production and quality. Trop. Anim. Health Prod. 2012, 44, 1035-1040. [CrossRef] [PubMed]

99. Donsbough, A.L.; Powell, S.; Waguespack, A.; Bidner, T.D.; Southern, L.L. Uric acid, urea, and ammonia concentrations in serum and uric acid concentration in excreta as indicators of amino acid utilization in diets for broilers. Poult Sci. 2010, 89, 287-294. [CrossRef] [PubMed]

100. Sova, M. Antioxidant and antimicrobial activities of cinnamic acid derivatives. Mini-Rev. Med. Chem. 2012, 12, 749-767. [CrossRef]

101. Siti, N.W.; Bidura, I.G.N.G.; Mayuni, S.N.; Utami, I.A. Effect of Moringa oleifera leaf powder in diets on feed digestibility and external egg quality characteristics in laying hens. J. Biol. Chem. Res. 2019, 36, 80-87. 
102. Scalbert, A.; Manach, C.; Morand, C.; Rémésy, C.; Jiménez, L. Dietary polyphenols and the prevention of diseases. Crit. Rev. Food Sci. Nutr. 2005, 45, 287-306. [CrossRef] [PubMed]

103. Abou-Elezz, F.M.K.; Sarmiento-Franco, L.; Santos-Ricalde, R.; Solorio-Sanchez, F. Nutritional effects of dietary inclusion of Leucaena leucocephala and Moringa oleifera leaf meal on Rhode Island Red hens' performance. Cuban J. Agric. Sci. 2011, 45, 163-169.

104. Balami, A.G.; Abdu, P.A.; Wakawa, A.M.; Aluwong, T.; Oladele, S.B.; Enam, S.J. Humoral immune response of broilers fed with Moringa oleifera supplemented feed and vaccinated with an inactivated infectious bursal disease vaccine. Afr. J. Biomed. Res. 2018, 21, 57-60.

105. Rao, S.R.; Raju, M.V.L.N.; Prakash, B.; Rajkumar, U.; Reddy, E.P.K. Effect of supplementing Moringa (Moringa oleifera) leaf meal and pomegranate (Punica granatum) peel meal on performance, carcass attributes, immune and antioxidant responses in broiler chickens. Anim. Prod. Sci. 2019, 59, 288-294.

106. Karthivashan, G.; Arulselvan, P.; Alimon, A.; Safinar Ismail, I.; Fakurazi, S. Competing role of bioactive constituents in Moringa oleifera extract and conventional nutrition feed on the performance of Cobb 500 broilers. BioMed Res. Int. 2015, $2015,970398$. [CrossRef] [PubMed]

107. Cui, Y.M.; Wang, J.; Lu, W.; Zhang, H.J.; Wu, S.G.; Qi, G.H. Effect of dietary supplementation with Moringa oleifera leaf on performance, meat quality, and oxidative stability of meat in broilers. Poult. Sci. 2018, 97, 2836-2844. [CrossRef]

108. Ratshilivha, N.; Awouafack, M.D.; Du Toit, E.S.; Eloff, J.N. The variation in antimicrobial and antioxidant activities of acetone leaf extracts of 12 Moringa oleifera (Moringaceae) trees enables the selection of trees with additional uses. S. Afr. J. Bot. 2014, 92, 59-64. [CrossRef]

109. Bijal, A.; Bhumika, D. Antibacterial Activity and Phytochemical Screening of Different Parts of Moringa oleifera Against Selected Gram Positive and Gram Negative Bacteria. J. Pharm. Chem. Biol. Sci. 2015, 3, 421-425.

110. Jaiswal, D.; Rai, P.K.; Kumar, A.; Mehta, S.; Watal, G. Effect of Moringa oleifera Lam. leaves aqueous extract therapy on hyperglycemic rats. J. Ethnopharmacol. 2009, 123, 392-396. [CrossRef] [PubMed]

111. Patel, N.; Mohan, J.S.S. Antimicrobial activity and phytochemical analysis of Moringa oleifera Lam. crude extracts against selected bacterial and fungal strains. Int. J. Pharmacogn. Phytochem. Res. 2018, 10, 68-79.

112. Desta, G.; Yalemtsehay, M.; Girmai, G.; Wondwossen, E.; Kahsay, H. The effects of Moringa stenopetala on blood parameters and histopathology of liver and kidney in mice. Ethiop. J. Health 2011, 25, 51-57.

113. Mariana, R.-A.; Cecilia, J.-P.; Carlos, J.-W.; Jesús, R.-G.; Alejandro, Á.-E.; David, S.-C. Inclusion of the Moringa oleifera leaf on immunological constants in broiler chickens. Abanico Vet. 2018, 8, 68-74.

114. Mohamed, A.N.; Ahmed, G.A.; Dina, M.B. Antiviral Potential of Leaf Extracts from Moringa oleifera and Rosemary (Rosmarinus officinalis Lam.). Egypt. J. Microbiol. 2017, 52, 129-139.

115. Aondo, T.O.; Odiaka, N.I.; Akesa, T.M.; Olaleye, O.O. Phytochemical and antifungal efficacy of different parts of Moringa oleifera plant extracts. Asian J. Biotechnol. Bioresour. Technol. 2018, 3, 1-8. [CrossRef]

116. Fadunsin, S.D.; Ademola, I.O. Direct effects of Moringa oleifera Lam (Moringaceae) acetone leaf extract on broiler chickens naturally infected with Eimeria species. Trop. Anim. Health Prod. 2013, 45, 1423-1428. [CrossRef] [PubMed]

117. Banna, H.A.; Atef, M.; Nabil, G. Anti-coccidial activity of Moringa oleifera plant. Anim. Vet. Sci. 2016, 4, 19. [CrossRef]

118. Gadelhaq, S.M.; Arafa, W.M.; Abolhadid, S.M. In vitro activity of natural and chemical products on sporulation of Eimeria species oocysts of chickens. Vet. Parasitol. 2018, 251, 12-16. [CrossRef] [PubMed]

119. Mahmood, S.; Rehman, A.; Yousaf, M.; Akhtar, P.; Hayat, G.A.K.; Shahzad, M.K. Comparative efficacy of different herbal plant's leaf extract on haematology, intestinal histomorphology and nutrient digestibility in broilers. Adv. Zool. Bot 2015, 3, 11-16. [CrossRef]

120. Ajantha, A.; Kathirvelan, C.; Purushothaman, M.R.; Visha, P. Effect of Moringa oleifera leaf meal supplementation in broiler chicken on serum and muscle lipid profile. J. Pharmacogn. Phytochem. 2020, 9, 464-466.

121. Sreelatha, S.; Padma, P.R. Antioxidant activity and total phenolic content of Moringa oleifera leaves in two stages of maturity. Plant Foods Human Nutr. 2009, 64, 303-311. [CrossRef]

122. Chumark, P.; Khunawat, P.; Sanvarinda, Y.; Phornchirasilp, S.; Morales, P.N.; Phivthong-ngam, L.; Ratanachamnong, P.; Srisawat, S.; Pongrapeeporn, K.S. The in vitro and ex vivo antioxidant properties, hypolipidaemic and antiatherosclerotic activities of the water extract of Moringa oleifera Lam. leaves. J. Ethnopharmacol. 2008, 116, 439-446. [CrossRef]

123. Stohs, S.J.; Hartman, M.J. Review of the safety and efficacy of Moringa oleifera. Phytother. Res. 2015, 29, 796-804. [CrossRef]

124. Melesse, A.; Steingass, H.; Boguhn, J.; Rodehutscord, M. In vitro fermentation characteristics and effective utilisable crude protein in leaves and green pods of Moringa stenopetala and Moringa oleifera cultivated at low and mid-altitudes. J. Anim. Physiol. Anim. Nutr. 2013, 97, 537-546. [CrossRef]

125. Alabi, O.J.; Ng'ambi, J.W.; Mbajiorgu, E.F. Aqueous extract of Moringa (Moringa oleifera) leaf (aemol) on the growth, sensory and histology parameters of broiler chickens. Appl. Ecol. Environ. Res. 2020, 18, 6753-6764. [CrossRef]

126. Ghazalah, A.A.; Ali, A.M. Rosemary leaves as a dietary supplement for growth in broiler chickens. Int. J. Poult. Sci. 2008, 7, 234-239. [CrossRef]

127. Teixeira, E.M.B.; Carvalho, M.R.B.; Neves, V.A.; Silva, M.A.; Arantes-Pereira, L. Chemical characteristics and fractionation of proteins from Moringa oleifera Lam. Leaves. Food Chem. 2014, 147, 51-54. [CrossRef] 
128. Nouman, W.; Basra, S.M.A.; Siddiqui, M.T.; Yasmeen, A.; Gull, T.; Alcayde, M.A.C. Potential of Moringa oleifera L. as livestock fodder crop: A review. Turk. J. Agric. Forest. 2014, 38, 1-14. [CrossRef]

129. Briones, J.; Leung, A.; Bautista, N.; Golin, S.; Caliwag, N.; Carlos, M.A.; Guevarra, J.; Miranda, J.; Guevarra, J.K.; Pili, N.L.; et al. Utilization of Moringa oleifera Lam. in Animal Production. Acta Hortic. 2015, 1158, 467-474. [CrossRef]

130. Onu, P.N.; Aniebo, A.O. Influence of Moringa oleifera leaf meal on the performance and blood chemistry of starter broilers. Inter. J. Food Agric. Vet. Sci. 2011, 1, 38-44.

131. Akhouri, S.; Prasad, A.; Ganguly, S. Moringa oleifera Leaf Extract Imposes Better Feed Utilization in Broiler Chicks. J. Biol. Chem. Res. 2013, 30, 447-450.

132. Abdulla, M.A.; Ahmed, K.A.; AL-Bayaty, F.H.; Masood, Y. Gastroprotective effect of Phyllanthus niruri leaf extract against ethanol-induced gastric mucosal injury in rats. Afr. J. Pharm. Pharacol. 2010, 4, 226-230.

133. Ambali, A.G.; Furo, N.A. An Investigation into the Phytochemical Constituents of Moringa oleifera Aqueous Root Extracts. Ph.D. Thesis, University of Maiduguri, Maiduguri, Nigeria, 2012.

134. Siddhuraju, P.; Becker, K. Antioxidant properties of various solvent extracts of total phenolic constituents from three different agroclimatic origins of drumstick tree (Moringa oleifera Lam.) leaves. J. Agric. Food Chem. 2003, 51, 2144-2155. [CrossRef] [PubMed]

135. Hekmat, S.; Morgan, K.; Soltani, M.; Gough, R. Sensory evaluation of locally-grown fruit purees and inulin fibre on probiotic yogurt in mwanza, Tanzania and the microbial analysis of probiotic yogurt fortified with Moringa oleifera. J. Health Popul. Nutr. 2015, 33, 60 .

136. Qwele, K.; Hugo, A.; Moyo, S.O.O.B.; Masika, P.J.; Muchenje, V. Chemical composition, fatty acid content and antioxidant potential of meat from goats supplemented with Moringa (Moringa oleifera) leaves, sunflower cake and grass hay. Meat Sci. 2013, 93, 455-462. [CrossRef] [PubMed]

137. Saini, R.K.; Shetty, N.P.; Prakash, M.; Giridhar, P. Effect of dehydration methods on retention of carotenoids, tocopherols, ascorbic acid and antioxidant activity in Moringa oleifera leaves and preparation of a RTE product. J. Food Sci. Technol. 2014, 51, 2176-2182. [CrossRef]

138. Miliauskasa, G.; Venskutonisa, P.R.; Van Beek, T.A. Screening of radical scavenging activity of some medicinal and aromatic plant extracts. Food Chem. 2004, 85, 231-237. [CrossRef]

139. Rahman, H.; Qureshi, M.S.; Khan, R.U. Influence of dietary zinc on semen traits and seminal plasma antioxidant enzymes and trace minerals of Beetal bucks. Reprod. Domest. Anim. 2014, 48, 1004-1007. [CrossRef] [PubMed]

140. Sultan, A.; Obaid, H.; Khan, S.; Rehman, I.U.; Shah, M.K.; Khan, R.U. Nutritional effect of flaxseeds on cholesterol profile and fatty acids composition in egg yolk. J. Cereal Chem. 2015, 92, 50-52. [CrossRef]

141. Ullah, H.; Khan, R.U.; Tufarelli, V.; Laudadio, V. Selenium: An essential micronutrient for sustainable dairy cows production. Sustainability 2020, 12, 10693. [CrossRef]

142. Khan, R.U.; Naz, S.; Dhama, K.; Saminathan, M.; Tiwari, R.; Jeon, G.J.; Laudadio, V.; Tufarelli, V. Modes of action of and beneficial applications of chromium in poultry nutrition, production and health: A review. Int. J. Pharmacol. 2014, 10, 357-363. [CrossRef]

143. Khan, R.U. Antioxidants and poultry semen quality. World's Poult. Sci. J. 2011, 67, 297-308. [CrossRef]

144. Kasetti, R.B.; Nabi, S.A.; Swapna, S.; Apparao, C. Cinnamic acid as one of the antidiabetic active principle(s) from the seeds of Syzygium alternifolium. Food Chem. Toxicol. 2012, 50, 1425-1431. [CrossRef]

145. Jung, S.; Choe, J.H.; Kim, B.; Yun, H.; Kruk, Z.A.; Jo, B. Effect of dietary mixture of gallic acid and linoleic acid on antioxidative potential and quality of breast meat from broilers. Meat Sci. 2010, 86, 520-526. [CrossRef] [PubMed]

146. Bennett, R.N.; Mellon, F.A.; Foidl, N.; Pratt, J.H.; Dupont, M.S.; Perkins, L.; Kroon, P.A. Profiling glucosinolates and phenolics in vegetative and reproductive tissues of the multi-purpose trees Moringa oleifera L. (horseradishtree) and Moringa stenopetala L. J. Agric. Food Chem. 2003, 51, 3546-3553. [CrossRef]

147. Cheenpracha, S.; Park, E.J.; Yoshida, W.Y.; Barit, C.; Wall, M. Potential antiinflammatory phenolic glycosides from the medicinal plant Moringa oleifera fruits. Bioorganic Med. Chem. 2010, 18, 6598-6602. [CrossRef]

148. Charoensin, S.; Wongpoomchai, R. Effect of aqueous extract of Moringa oleifera leaves on quinone reductase activity. Naresuan Phayao J. 2012, 5, 101-109.

149. Luqman, S.; Srivastava, S.; Kumar, R.; Maurya, A.K.; Chanda, D. Experimental assessment of Moringa oleifera leaf and fruit for its antistress, antioxidant, and scavenging potential using in vitro and in vivo assays. Evid. Based Complement. Alternat. Med. 2012, 2012, 1-12. [CrossRef]

150. Santos, A.F.; Argolo, A.C.; Paiva, P.M.; Coelho, L.C. Antioxidant activity of Moringa oleifera tissue extracts. Phytother. Res. 2012, 26, 1366-1370. [CrossRef]

151. Teye, G.A.; Baffoe, F.; Teye, M. Effects of Moringa (Moringa oleifera) Leaf Powder and Dawadawa (Parkia biglobosa), on Sensory Characteristics and Nutritional Quality of Frankfurter-Type Sausages-A Preliminary Study. Glob. Adv. Res. J. Agric. Sci. 2013, 2, 29-33.

152. Kamanyi, A.; Njamen, D.; Nkeh, B. Hypoglycaemic properties of the aqueous extract of Morinda lucida (Benth)(Rubiaceae). Studies in the mouse. Phytother. Res. 1994, 8, 369-371. [CrossRef]

153. Dzotam, J.K.; Touani, F.K.; Kuete, V. Antibacterial and antibiotic-modifying activities of three food plants (Xanthosoma mafaffa Lam.; Moringa oleifera (L.) Schott and Passiflora edulis Sims) against multidrug-resistant (MDR) Gram-negative bacteria. BMC Complementary Altern. Med. 2015, 16, 1-8. [CrossRef] 
154. Bichi, M.H.; Shehu, U.H. Antimicrobial properties of Moringa oleifera seed oil. Int. J. Res. Earth Environ. Sci. 2018, 13, 1-5.

155. Allam, H.; Abdelazem, A.M.; Farag, H.S.; Hamed, A. Some hemato-biochemical, bacteriological and pathological effects of Moringa oleifera leaf extract in broilerchicken. Int. J. Basic Appl. Sci. 2016, 5, 99. [CrossRef]

156. Jabeen, R.; Shahid, M.; Ashraf, M. Microscopic evaluation of the antimicrobial activity of seed extracts of Moringa oleifera. Pak J. Bot. 2008, 40, 1349-1358.

157. Anwar, F.; Ashraf, M.; Bhanger, M.I. Interprovenance variation in the composition of Moringa oleifera oilseeds from Pakistan. J. Am. Oil Chem. Soc. 2005, 82, 45-51. [CrossRef]

158. Hefni, M. Imunomodulator Activity of Aqueous Extract of Moringa oleifera Lam on Immunity Response of mice (Mus Musculus) Which Infected with Salmonella Typhi. Master's Thesis, University of Brawijaya, Malang, Indonesia, 2013.

159. Abousekken, M.S.M. Performance, immune response and carcass quality of broilers fed low protein diets contained either Moringa oleifera leaves meal or its extract. J. Am. Sci. 2015, 11, 153-164.

160. Katanbaf, M.N.; Dunnington, E.A.; Siegel, P.B. Restricted feeding in early and late- feathering chickens. Growth and physiologyical responses. Poult. Sci. 1989, 2, 188-191.

161. Lannaon, W.J. Herbal plants as source of antibiotics for broilers. Agric. Mag. 2007, 11, 55.

162. Eilert, U.; Wolters, B.; Nahrsted, A. The antibiotic principle of Moringa oleifera and Moringa stenopetala. Planta Med. 1981, $42,55-61$. [CrossRef]

163. Walter, A.; Samuel, W.; Peter, A.; Joseph, O. Antibacterial activity of Moringa oleifera and Moringa stenopetala methanol and n-hexane seed extracts on bacteria implicated in water borne diseases. Afr. J. Microbiol. Res. 2011, 5, $153-157$.

164. Allen, P.C.; Fetter, R.H. Recent advances in biology and immunobiology of Eimeria species and in diagnosis and control of infection with these coccidian parasites of poultry. Clin. Microbiol. Rev. 2002, 15, 58-65. [CrossRef] [PubMed] 